\title{
EL TERCER PROYECTO DE CONCORDATO ENTRE Chile y la Santa Sede en 1928. TEXTO Y COMENTARIO
}

[The Third Concordat Project Between Chile and the Holy See in 1928.

Text and Remarks]

\author{
Carlos Salinas Araneda* \\ Pontificia Universidad Católica de Valparaíso, Chile**
}

\begin{abstract}
Resumen
La reciente apertura de los fondos documentales del pontificado de Pío XI guardados en el Archivo Secreto del Vaticano ha permitido conocer tres proyectos de concordato entre Chile y la Santa Sede redactados en 1928 , una vez producida la separación entre la Iglesia y el Estado merced a la Constitución de 1925. Después de haber publicado en esta misma revista los dos proyectos presentados por el gobierno de Chile, se presenta ahora el tercero de dichos proyectos, redactado por el nuncio
\end{abstract}

\begin{abstract}
The recent opening of documentary collections of the pontificate of Pius XI that are kept in the Vatican Secret Archives has allowed us to become acquainted with the three concordant projects between Chile and the Holy See, written on 1928 after the separation of Church and State by the Constitution of 1925. After publishing, in this magazine, both projects presented by the Chilean Government, this third project was written by the apostolic nuncio and
\end{abstract}

ReCibido el 6 de marzo y ACEPTADo el 10 de mayo de 2014

* Catedrático de Historia del Derecho y Derecho Canónico en la Pontificia Universidad Católica de Valparaíso. Dirección postal: Facualtad de Derecho, Pontificia Universidad Católica de Valparaíso, casilla 4059, Valparaíso, Chile. Dirección electrónica: csalinas@ucv.cl.

** Esta investigación ha sido realizada con ocasión del Proyecto Fondecyt 1120345 del que su autor es investigador responsable. 
apostólico y presentado al ministro de Relaciones Exteriores. Cada uno de los atículos va acompañado de un comentario que muestra los cambios introducidos por el nuncio a los proyectos del gobierno y la regulación que posteriormente ha dado a cada uno de los temas el moderno derecho concordatario.

\section{Palabras Clave}

Relaciones Iglesia-Estado en Chile - Proyectos de concordato de 1928 Relaciones Chile-Santa Sede. presented to the Ministry of Foreign Relations. Each article includes remarks on the changes made by the nuncio to the government projects and the regulations that the modern concordat law applied for each subject.

\section{KEYWORDS}

Church-State relationships in Chile - 1928 Concordat projects - Chile and the Holy See relationships.

\section{INTRODUCCIÓN}

El miércoles 30 de mayo de 1928, el nuncio de Su Santidad en Chile, el arzobispo Ettore Felici, envió un despacho al secretario de Estado de Pío XI (1922-1939), cardenal Pedro Gasparri ${ }^{1}$, en que le comunicaba que, en audiencia que le había concedido el ministro de Relaciones Exteriores, Conrado Ríos Gallardo, el miércoles anterior, 23 de mayo, le había hecho entrega de un proyecto de concordato que era esperado desde hacía algunas semanas; el mismo ministro le había pedido al nuncio que lo examinara y que se lo restituyera lo más pronto, acompañado de sus observaciones. Dicho proyecto, al que denomino "Proyecto II", había sido precedido de otro, presentado pocos días antes por el embajador de Chile ante la Santa Sede, don Ramón Subercaseaux, el 1 de mayo de 1928, que he denominado "Proyecto I". Ambos proyectos son similares, aunque el "Proyecto II" introduce algunas modificaciones que no son menores, especialmente orientadas a acentuar las posibilidades de intervención del Estado en los asuntos internos de la Iglesia, que había perdido al producirse, en 1925, la separación entre la Iglesia y el Estado ${ }^{3}$. Cuando el nuncio en Chile recibió el "Proyecto II", encontró en él una serie de materias que no eran aceptables en la forma en que estaban

${ }^{1}$ Archivio Segreto Vaticano, Sacra Congregazione degli Affari Ecclesiastici Straordinari, Cile 1927-1928. Pos. 283-285 PO. Fasc. 47. pp. 43-46. Esta documentación ha sido transferida en el verano europeo de 2012 al Archivo de la Secretaría de Estado donde actualmente se encuentra.

${ }^{2}$ Salinas Araneda, Carlos, Un primer proyecto de concordato entre Chile y la Santa Sede, en Revista Chilena de Derecho, 39 (2012), pp. 665-698.

${ }^{3}$ Salinas Araneda, Carlos, Un intento de neo-regalismo en el siglo XX: los proyec- 
reguladas, por lo que presentó un contraproyecto, que constituye un nuevo documento al que denominaré "Proyecto III" que es el que ahora presento. Este "Proyecto III", redactado por el nuncio y entregado al gobierno, junto con el "Proyecto II" que le había presentado informalmente el gobierno, fueron enviados por el nuncio al cardenal secretario de Estado, junto a una extensa carta en la que le proporcionaba algunas explicaciones respecto de algunos artículos que le preocupaban particularmente.

$\mathrm{Al}$ presentar el primero de estos proyectos, analicé su articulado a la luz de la experiencia histórica chilena en los diversos temas que eran abordados, temas que desde el período indiano habían interesado a la Iglesia y a la monarquía española y que, producida la independencia, siguieron interesando a la Iglesia, ahora en relación con los gobiernos republicanos que se sucedieron en Chile. Presento ahora este tercer proyecto, elaborado por el nuncio, que bien podríamos denominar c o n t r a - p r o y e c t o, haciendo un breve comentario a cada uno de sus artículos en que pongo de relieve, por una parte, los comentarios hechos por el nuncio en su carta al cardenal Gasparri y, por otra, lo que se ha seguido en el moderno derecho concordatario respecto de cada una de las materias abordadas por el nuncio en el articulado de este nuevo proyecto que él propuso.

\section{El TEXTO DEL “Proyecto III” Y UN COMENTARIO}

\section{Artículo 1}

"La Iglesia Católica gozará en el territorio de la República de Chile deplena independencia en el ejercicio de su ministerio espiritual, y de todas las libertades necesarias para el cumplimiento de su divina misión".

Con este artículo se iniciaba el texto del proyecto de concordato sugerido por el nuncio y venía a ser más bien una declaración de principios que definía la necesaria independencia y libertad de que debía gozar la Iglesia en Chile para el cumplimiento de su misión. Se modificaba el artículo primero de los dos proyectos anteriores ${ }^{4}$, en el sentido de agregar a la $\mathrm{l}$ i b e r t a d la i n d e p e n d e n c i a, y se eliminaba la referencia que en esos artículos se hacía a la erección y conservación de templos. Con esta nueva redacción el artículo abría el articulado con una declaración concisa y homogénea en

tos de concordato entre Chile y la Santa Sede en 1928, en Anuario Jurídico y Económico Escurialense, 47 (2014), pp. 501-528.

4 "Proyecto I", artículo 1; "Proyecto II", artículo 1: "La Iglesia católica gozará en el territorio de la República de Chile de plena libertad y podrá erigir y conservar templos y sus dependencias con las condiciones de seguridad e higiene fijadas por las leyes y ordenanzas que rijan en Chile sobre la materia". 
su contenido sin mezclar materias como lo hacían los proyectos anteriores y con ella se aseguraba a la Iglesia la libertad ad extra que requiere para el cumplimiento de su divina misión. En el artículo siguiente, como se verá, se aseguraba la libertad ad intra.

Se trataba de una cláusula concordataria que se encuentra generalizadamente en los concordatos, como ocurre con los concordatos postconciliares vigentes en América Latina ${ }^{5}$, en concreto Argentina (1966, artículo 1), Colombia (1973, artículo 2), Brasil (2008, artículo 2), en los que, con fórmulas no siempre iguales, se afirma la libertad de la iglesia y el compromiso del Estado de respetarla. Particularmente interesante es el artículo 2 del acuerdo con Brasil, que fundamenta en el derecho de libertad religioso el derecho de la Iglesia de desempeñar su misión espiritual. A decir verdad, después que la Iglesia reconociera el derecho de libertad religiosa en el Concilio Vaticano $\mathrm{II}^{6}$, ha dejado de pedir privilegios al firmar sus acuerdos con los Estados, limitándose tan solo a pedir que esos, en cumplimiento de la libertad religiosa que proclaman normalmente en sus Constituciones, le permitan ejercer con libertad la misión espiritual que le es propia, en igualdad de condiciones con las otras confesiones religiosas; no más derechos que ellas, pero tampoco menos.

Artículo 2

"El Gobierno de Chile asegura a la Iglesia católica, en los organismos que de ella dependen, según el derecho canónico, el libre ejercicio de su poder espiritual $y$ de su jurisdicción eclesiástica, y le reconoce la personería jurídica de derecho público, que le es propia".

El artículo 2 de los dos proyectos del gobierno ${ }^{7}$ aseguraban a la Iglesia católica y a los organismos que de ella dependían el libre ejercicio de su poder espiritual y de su jurisdicción eclesiástica, con lo cual complementaban el artículo 1 en la medida que, mientras aquél le garantizaba la libertad ad extra, este artículo 2 garantizaba a la Iglesia su autonomía interna, sin que el

${ }^{5}$ Para el estudio de los textos concordatarios he utilizado Enchiridion dei concordati. Due secoli di storia dei rapporti Chiesa-Stato (2003) (Bologna, Dehoniane, 2003); y MARTín DE AGAR, José T., I concordati dal 2000 al 2009 (Città del Vaticano, Librería Editrice Vaticana, 2010).

${ }^{6}$ Concilio Vaticano II, Declaración 'Dignitatis humanae'(1965).

7 "Proyecto I", artículo 2: "El gobierno de Chile asegura a la Iglesia y a los organismos que de ella dependen el libre ejercicio de su poder espiritual y de su jurisdicción eclesiástica, lo mismo que la libre administración de sus bienes y negocios, conforme al derecho canónico $y$ a las leyes chilenas". En el "Proyecto II", el paso final "y a las leyes chilenas" es sustituido por "en cuanto no se oponga a las leyes chilenas". 
Estado pudiere interferir en sus estructuras y en su actuar; pero el artículo propuesto por el gobierno, además, aseguraba a la Iglesia y sus organismos la libre administración de sus bienes y negocios, conforme al derecho canónico y las leyes chilenas, elemento éste que el proyecto del nuncio dejaba de lado para tratarlo expresamente en el artículo siguiente. En cambio, agregaba un dato nuevo que estaba ausente en los dos proyectos gubernamentales: la personalidad jurídica de derecho público, la que, con una redacción poco clara, se extendía a la Iglesia "en los organismos que de ella dependen según el derecho canónico".

En efecto, en ninguna parte del articulado de los dos proyectos presentados por el gobierno se hacía referencia a que la Iglesia o alguna de sus entidades tuviese personalidad jurídica, no obstante que el concordato con Lituania, que el gobierno había tenido a la vista para la redacción de los mismos, hablaba expresamente de "personas jurídicas eclesiásticas y religiosas". Tal omisión no es de extrañar porque era uno de los temas discutidos en ese momento, una vez producida la separación Iglesia-Estado, pues había quienes entendían que, producida dicha separación, la Iglesia había perdido la calidad de persona jurídica de derecho público pasando a ser sólo persona jurídica de derecho privado?.

El tema preocupaba al nuncio porque las consecuencias que traía el que la Iglesia pasara a ser persona jurídica de derecho privado no eran menores conforme a la legislación que entonces estaba vigente ${ }^{10}$. En la carta con la que el nuncio envió al cardenal secretario de Estado el proyecto gubernamental que le había entregado el ministro de Relaciones Exteriores y el nuevo proyecto por él redactado, explicaba al cardenal la notable diferencia que había entre una y otra personalidad en lo referido a la posesión y administración de bienes inmuebles toda vez que, mientras las personas jurídicas de derecho público podían adquirir, conservar y administrar, sin ninguna limitación, las personas de derecho privado: $i$ ) una vez adquirido un inmueble, no podían conservarlo más allá de cinco años, sin una autorización legal concedida por una de las dos Cámaras; ii) si en el término antedicho no habían conseguido la

${ }^{8}$ Por ejemplo, artículos XVI, XVII, XXII.

${ }^{9}$ Por ejemplo, Alessandri Rodríguez, Arturo, Derecho civil. Primer Año (versiones taquigráficas de sus clases tomadas por Onías León Gaete) (Santiago, Zamorano y Caperán, 1943); BALmaCeda LAzCANo, C., El estatuto de las personas jurídicas (Santiago, Nascimento, 1943). Una buena síntesis en Alessandri Rodríguez, Arturo - Somarriva Undurraga, Manuel, Curso de Derecho Civil (redactado y puesto al día por Antonio Vodanovic, $3^{\text {a }}$ edición, Santiago, Nascimento, 1961), I, 2, pp. $276-$ 284. Una exposición de conjunto en Salinas Araneda, Carlos, Lecciones de derecho eclesiástico del Estado de Chile (Valparaíso, Ediciones Universitarias de Valparaíso de la Pontificia Universidad Católica de Valparaíso, 2004), pp. 267-280.

${ }^{10}$ Código Civil, artículos 556, 557. 
autorización referida, caía en comiso, y el bien pasaba al fisco; iii) aun cuando hubiesen sido autorizados a conservarlo, no podían venderlo o hipotecarlo sin una especial licencia del tribunal. Todavía más grave se presentaba la situación para las diócesis creadas después de la promulgación de la citada Constitución ${ }^{11}$, ya que, como advertía el nuncio, no faltaban juristas, "incluso católicos”, que, partiendo del principio que las personas de derecho privado no subsistían si no en fuerza de una ley o de un decreto, sostenían que las diócesis antedichas no tenían ninguna personalidad jurídica, pues no existía un decreto o una ley que las reconociese.

El mismo nuncio reconocía que, afortunadamente, no todos pensaban de tal modo, por lo que no le parecía difícil demostrar que, "según la letra de la Constitución”, la Iglesia continuaba gozando en Chile de la personalidad jurídica de derecho público, que le había sido reconocida "desde el tiempo de la colonización española”. Con todo, no excluía que la intención de los redactores del artículo 10 de la Constitución no hubiese sido "precisamente la de disminuir los derechos de la Iglesia”, por lo que consideraba urgente definir de una vez para siempre "la grave cuestión", aprovechando el concordato, el cual, aceptado por el gobierno y ratificado por las dos Cámaras, asumiría el valor de una interpretación auténtica de la Constitución y cortaría toda la discusión.

La tesis que finalmente se impuso fue que la nueva Constitución no había alterado la situación anterior, de manera que las “iglesias", las “comunidades religiosas", expresiones ambas utilizadas por el Código Civil (artículo 547 inciso $2^{\circ}$ ), y la misma Iglesia católica, conservaban su calidad de personas jurídicas de derecho público. En todo caso, así lo habían entendido los obispos de Chile quienes, en la pastoral colectiva que escribieron sobre la separación de la Iglesia y el Estado ${ }^{12}$, expresaban que "pasando a lo temporal, la nueva Constitución no innova en el reconocimiento ni en la organización de la personalidad jurídica de que gozaba la Iglesia bajo el imperio de la Constitución de 1833 y de las leyes existentes en el momento de su reforma".

En relación con la personalidad jurídica de la Iglesia en los concordatos post-conciliares, el panorama que ellos muestran es el siguiente: i) en algunos de ellos se reconoce la personalidad jurídica de la Iglesia católica y de diversas entidades eclesiásticas que se enuncian, como ocurre con el concordato con Colombia (1973, artículo IV), que en esta parte no ha

${ }^{11} \mathrm{El}$ mismo día de la entrada en vigencia de la nueva Constitución, el 18 de octubre de 1925, Pío XI erigió los obispados de San Felipe, Valparaíso, Rancagua, Talca, Linares, Chillán y Temuco; y el 14 de diciembre siguiente designó sus obispos residenciales.

${ }^{12}$ Obispos de Chile, Pastoral colectiva de los obispos de Chile, sobre la separación de la Iglesia y el Estado, en La Revista Católica, 578 (1925), pp. 488-491. 
sido declarado inconstitucional como ha ocurrido con otros artículos ${ }^{13}$; Perú (1980, artículo II-IV); Polonia (1993, artículo 4); Eslovenia (2001, artículo 2); Portugal (2004, artículo 1.2, 8-11); Brasil (2008, artículo 3). En el acuerdo con Israel sobre personalidad jurídica (1997) se reconoce la personalidad jurídica de "la misma Iglesia católica" y de las diversas entidades eclesiales que va numerando; ii) en otros acuerdos, después de reconocerse la personalidad jurídica de la Iglesia, se reconoce la personalidad jurídica de las instituciones eclesiásticas que, en general, tienen personalidad jurídica conforme al derecho canónico, sin entrar a enunciarlas, como ocurre en los acuerdos con Croacia (1996 acerca de cuestiones jurídicas, artículo 2); Gabón (1997 sobre disposiciones jurídicas, artículo $2 \S 2$ ), Estonia (1999, artículo 2), Lituania (2000 sobre cuestiones jurídicas, artículo 2); Letonia (2000, artículo 2); República Eslovaca (2000, artículo 1); iii) en el acuerdo con la República Eslovaca se dice que "La Santa Sede y la República Eslovaca se consideran reciprocamente sujetos independientes y autónomos de derecho internacional" (2000, artículo 1); algo similar ocurre en el acuerdo con la República Checa (2002, artículo 1); iv) en algunos acuerdos, en cambio, no se habla de la Iglesia católica, en general, sino que las referencias se hacen sólo a las diversas circunscripciones eclesiásticas e instituciones de vida consagrada, como ocurre con España (1979 sobre cuestiones jurídicas, artículo I) o con Kazakistán (1998, artículo 3); v) en cuanto a la calidad de la personalidad jurídica, algunos acuerdos hablan simplemente de "personalidad jurídica”, sin calificarla, como los mencionados de Colombia, España, Kazakistán, Estonia, Lituania sobre aspectos jurídicos, Letonia. Otros se refieren más específicamente a personalidad jurídica "de carácter público", como Perú, o Gabón (1997, artículo $2 \$ 1$ ), acuerdo este último en que se afirma que dicha personalidad la posee la Iglesia católica "por naturaleza"; o "personalidad jurídica pública", como el acuerdo jurídico con Croacia o el de Bosnia-Herzegovina (2006, artículo 2); vi) en el acuerdo con Albania (2002, artículo 2) se reconoce que la calidad de persona jurídica pública la tendrán las instituciones de la Iglesia "que gozan el mismo estatuto según el derecho canónico".

A la luz de lo anterior, me parece claro que: $i$ ) en algunos casos se reconoce expresamente la personalidad jurídica de derecho internacional de la Iglesia; ii) la personalidad jurídica de la Iglesia al interior de los ordenamien-

${ }^{13}$ En los últimos años se ha cuestionado por la Corte Constitucional de Colombia la constitucionalidad de algunos artículos del concordato sin que el artículo 24 se encuentre entre ellos. Cf. Prieto, Vicente, Los acuerdos vigentes entre Colombia y la Santa Sede, en Navarro Floria, Juan G. (coordinador), Acuerdos y concordatos entre la Santa Sede y lospaises americanos (Buenos Aires, Editorial de la Universidad Católica Argentina, 2011), pp. 180-182. 
tos jurídicos que han celebrado acuerdos con ella está fuera de dudas; iii) dicha personalidad jurídica no sólo es atributo de la Iglesia, sino también de las instituciones eclesiales que tienen personalidad jurídica conforme al derecho canónico; $i v$ ) en algunos casos se reconoce explícitamente que dicha personalidad jurídica es de derecho público, para lo cual se utilizan expresiones diversas pero que muestran la misma realidad; $v$ ) incluso, se ha llegado a otorgar dicha personalidad jurídica de derecho público en los ordenamientos estatales a aquellas entidades eclesiales que, conforme al derecho canónico, tengan personalidad jurídica canónica pública, haciéndose una total equivalencia entre unas y otras.

Artículo 3

"Todas las personas jurídicas eclesiásticas y religiosas, reconocidas como tales por el Derecho Canónico, gozarán, por consiguiente, de plena libertad para adquirir, a titulo oneroso o gratuito, toda clase de bienes, muebles o inmuebles, para poseerlos, administrarlos, gravarlos o enajenarlos, conforme al derecho canónico y a las leyes actualmente en vigor para las personas juridicas de derecho público, como también para comparecer ante las autoridades del Estado en resguardo de sus derechos civiles".

Se trataba de un artículo nuevo que se redactaba recogiendo, por un lado, aquella parte del artículo 2 de los dos proyectos gubernamentales en los que se aseguraba a la Iglesia y a los organismos que dependían de ella, la libre administración de sus bienes y negocios conforme al derecho canónico y a las leyes chilenas; y, por otra, el artículo 20 del "Proyecto I" ${ }^{14}$ que pasó a ser el artículo 18 del "Proyecto II", según los cuales las iglesias, los ordinarios, las parroquias y las comunidades religiosas legalmente establecidas en Chile estaban facultadas para adquirir, poseer, ceder y administrar bienes ciñéndose al derecho canónico y conforme a la legislación chilena.

El proyecto del nuncio le daba autonomía a esta libertad, la que conectaba con la personalidad jurídica de derecho público, interesado como estaba de que ésta quedara firmemente asentada. Esta "plena libertad" es una consecuencia - "por consiguiente"- de dicha personalidad jurídica de derecho público, y disfrutaban de ella "todas las personas eclesiásticas y religiosas reconocidas como tales por el derecho canónico”, esto es, las que el Código Civil de-

14 "Proyecto I", artículo 20; "Proyecto II", artículo 18: "Conforme a la legislación chilena, las iglesias, los ordinarios, las parroquias y las comunidades religiosas legalmente establecidas en Chile estarán facultadas para adquirir, poseer, ceder y administrar, ciñéndose a las reglas del derecho canónico, sus bienes muebles e inmuebles, como también para comparecer ante las autoridades del Estado en resguardo de sus derechos civiles". 
nominaba "iglesias" y "comunidades religiosas". El texto del artículo las dejaba bien resguardadas y quedaban superadas las dudas del diplomático vaticano.

El concordato con Colombia (1973, artículo XXIII) reconocía, bajo la vigencia del código canónico de 1917, a la Iglesia católica y demás personas jurídicas -diócesis, comunidades religiosas y otros entes eclesiásticos a los que las leyes canónicas le reconocen personalidad jurídica- la facultad de adquirir, poseer, enajenar y administrar libremente bienes muebles e inmuebles en la forma establecida por la legislación colombiana para todos los ciudadanos, disposición concordataria que está entre las que no ha sido acusadas de inconstitucionales ${ }^{15}$. Y entre los otros concordatos recientes, el mismo derecho se reconoce a las personas jurídicas de la Iglesia católica en el acuerdo sobre cuestiones jurídicas con Lituania (2000, artículo 10), en el acuerdo sobre cuestiones jurídicas con Eslovenia (2001, artículo 9) y en el acuerdo base con Bosnia y Herzegovina (2006, artículo 10).

\section{Artículo 4}

"[Inciso $\left.1^{\circ}\right]$ Los eclesiásticos, sus bienes y los de las personas jurídicas eclesiásticas y religiosas (obispados, cabildos, parroquias, comunidades religiosas, seminarios, etc.) quedan sometidos a impuestos del mismo modo que laspersonas y los bienes de los ciudadanos de la República y que las personas jurídicas laicas de derecho público.

[Inciso $2^{\circ}$ ] Estarán, sin embargo, exentos de contribuciones los templos $y$ sus dependencias, dedicados al servicio del culto católico; las residencias episcopales y parroquiales con sus dependencias; los conventos, hospitales, hospicios, orfelinatos, y en general, los locales de instituciones católicas destinadas a dar auxilio o habitación gratuita a los desvalidos, en la parte afecta a tales servicios; los seminarios, las universidades, las escuelas y colegios católicos.

[Inciso $\left.3^{\circ}\right]$ Quedarán también exentos de pago de contribuciones los bienes destinados al mantenimiento de las instituciones de beneficencia y de instrucción expresados en el inciso anterior".

En tres incisos, el artículo reproducía el artículo $3^{16}$ de los dos proyectos

${ }^{15}$ Prieto, Vicente, cit. (n. 13), p. 183.

16 "Proyectos I y II", artículo 3: "Los eclesiásticos, sus bienes y los de las iglesias, ordinarios, parroquias y comunidades religiosas quedan sometidos a impuestos del mismo modo que las personas y los bienes de los ciudadanos de la república y de las personas jurídicas laicas, pero estarán exentos de contribuciones los templos y sus dependencias, destinados al servicio del culto católico, las casas parroquiales y de residencia de los ordinarios, los hospitales, hospicios, orfelinatos y, en general, los locales de instituciones católicas destinadas a dar auxilio o habitación gratuita a los desvalidos, en la parte afecta a tales servicios y siempre que ninguna porción de su renta sea destinada a fines de lucro personal y los locales 
gubernamentales los que, en un solo inciso, regulaban las materias recogidas en los dos primeros incisos de este artículo, del que el inciso $3^{\circ}$ es nuevo. En el inciso $1^{\circ}$ se ha introducido el concepto de persona jurídica eclesiástica tan importante para el nuncio y se enunciaban algunas a modo de ejemplo, de las cuales los "ordinarios, las parroquias y comunidades religiosas" eran mencionados en aquellos. Además, a la expresión "personas jurídicas laicas" con que terminaba el inciso $1^{\circ}$ y que se usaba en los dos proyectos anteriores, se ha agregado el adjetivo “de derecho público". En el inciso $2^{\circ}$ de han agregado las "dependencias" de las residencias episcopales y parroquiales, y también los conventos y se han eliminado las referencias a que la exención es sólo si los bienes no producen rentas. El inciso $3^{\circ}$ es nuevo. En conjunto, este artículo 4 , a la vez que afirmaba la obligación de las personas eclesiales, naturales y jurídicas, de pagar impuestos al igual que el resto de los ciudadanos, reconocía la exención del pago de contribuciones territoriales para algunos inmuebles vinculados a la Iglesia, a sus personas o a sus actividades.

En el concordato con Colombia (1973, artículo XXIV), artículo cuya constitucionalidad no ha sido cuestionada ${ }^{17}$, se afirma el principio general de que "las propiedades eclesiásticas podrán ser gravadas en la misma forma y extensión que las de los particulares", quedando exceptuados "en consideración a su peculiar finalidad" los edificios destinados al culto, las curias diocesanas, las casas episcopales y curales y los seminarios. Los bienes de utilidad común sin ánimo de lucro, así como los destinados a obras de culto, de educación o beneficencia, se regirán en materia tributaria "por las disposiciones legales establecidas para las demás instituciones de la misma naturaleza". En el acuerdo sobre cuestiones económicas con España (1979) se reconocen diversas exenciones tributarias a las instituciones eclesiásticas que en cada caso se mencionan, referidas a tributos variados, como renta, contribución territorial, herencias y donaciones y otros. En el concordato con Perú (1980, artículo X), se hace una referencia genérica a que "la Iglesia católica y las jurisdicciones y comunidades religiosas que la integran" continuarían gozando de las exenciones y beneficios tributarios y franquicias "que les otorgan las leyes y normas legales vigentes”. En la revisión italiana del concordato lateranense (1984, artículo 7.3), a efectos tributarios, se equiparan a las entidades con fines de beneficencia y de instrucción los entes eclesiásticos y sus actividades con fines de religión y de culto así como las actividades dirigidas a tal efecto.

Más modesto es el concordato con Polonia (1993, artículo 21. 2) que exime de las normas sobre colectas públicas las ofrendas recogidas para

de los seminarios, universidades, escuelas y colegios católicos en la parte afecta a servicios de instrucción y que no produzcan rentas".

${ }^{17}$ Prieto, Vicente, cit. (n. 13), pp. 178-179. 
fines religiosos, actividades eclesiásticas, caritativo-asistenciales, científicas, instructivas y educativas, así como las dirigidas al mantenimiento del clero y de los religiosos en tanto que se realicen en el ámbito territorial eclesiásticos, capillas y lugares y circunstancias definidas por la costumbre. En el acuerdo jurídico sobre cuestiones económicas con Croacia (1993, artículo 10), para fines tributarios, las personas jurídicas de la Iglesia católica serán consideradas instituciones sin fin de lucro, salvo cuando realicen actividades con fines de lucro. En el acuerdo sobre asuntos jurídicos con Lituania (2000, artículo 10), las personas jurídicas canónicas así como diversos lugares -iglesias, capillas, casas parroquiales, seminarios- quedan exentos de impuestos estatales, así como las ofrendas para actividades pastorales, educativas y caritativas. En cambio, la propiedad e ingresos destinados a fines diversos, quedan sometidos a las leyes generales. En el acuerdo base con la República Eslovaca (2000, artículo 20), sin perjuicio de un futuro acuerdo sobre materias financieras, las colectas realizadas en las iglesias no están sometidas a tributo ni obligadas a contabilidad pública. En Bosnia-Herzegovina (2006, artículo 17), las instituciones eclesiásticas con fines asistenciales y caridad gozan de los mismos derechos, privilegios y tratamiento que las instituciones estatales destinadas a las mismas finalidades. Brasil (2008, artículo 15) garantiza a las personas jurídicas eclesiásticas así como al patrimonio, rentas y servicios relacionados con su finalidad esencial la inmunidad tributaria referida a los impuestos "en conformidad con la Constitución brasileña", y las personas jurídicas de la Iglesia católica que desarrollen actividades sociales y educativas sin fines de lucro recibirán el mismo tratamiento y beneficios de atribuidos a los entes filantrópicos reconocidos por el ordenamiento jurídico brasileño.

En fin, como puede verse de este rápido repaso, del que todavía quedan fuera otros acuerdos, hay generalizadamente en los años posteriores al Concilio Vaticano II y en los más recientes una actitud de cooperación de los Estados para con la Iglesia a efectos de que ella pueda desarrollar no sólo con libertad, sino con bajos costos en la medida que el Estado pueda colaborar en ello, las actividades cultuales y de caridad que le son propias. Esto, claro está, no es un privilegio exclusivo de la Iglesia, sino que se extiende también a las otras instituciones que cumplen fines similares, como los mismos acuerdos se encargan de poner de relieve.

\section{Artículo 5}

"Los obispo, el clero y los fieles podrán comunicarse libremente y directamente con la Santa Sede, y en la misma forma podrán los obispos comunicarse con el clero y fieles de su dependencia, y publicar sus pastorales y ordenanzas".

Recogía en términos similares, con leves cambios de redacción, el artículo 
4 del "Proyecto I" ${ }^{18}$, que seguía de cerca el artículo II del concordato con Lituania, que se repitió en el artículo 4 del "Proyecto II"19 con un añadido, pues había agregado la frase final "siempre que no contrarien las leyes chilenas", frase que el nuncio eliminaba en su proyecto.

Se trata de una cláusula que está frecuentemente presente en los concordatos y que es posible leer en los acuerdos recientes con Lituania (2000, sobre aspectos jurídicos, artículo 3), Eslovenia (2001, artículo 6), Portugal (2004, artículo 2), Bosnia y Herzegovina (2006, artículo 3). Sin embargo, la fórmula empleada por el proyecto del nuncio garantiza la libre comunicación desde Chile hacia Roma, pero guarda silencio en lo que se refiere a la comunicación de Roma con Chile en circunstancias que el concordato con Portugal, por ejemplo, afirma expresamente que "la Santa Sedepuede aprobar y publicar libremente cualquier norma, disposición o documento relativo a la actividad de la Iglesia y comunicar sin impedimento con los obispos, el clero y los fieles, pudiendo estos hacer otro tanto con la Santa Sede".

\section{Artículo 6}

"Las autoridades chilenas prestarán su apoyo para la ejecución de las decisiones y de los decretos eclesiásticos en caso de destitución de un eclesiástico, de probibición del ejercicio del ministerio sacerdotal en locales públicos destinados al culto o del uso del hábito eclesiástico, y asegurarán el resguardo del orden en actos o manifestaciones religiosas en lugares públicos y en las otras circunstancias en que prescriban o permitan tal apoyo las leyes chilenas".

Repetía este artículo, con leves modificaciones en la redacción, el texto del artículo 5 de los dos proyectos gubernamentales ${ }^{20}$, si bien eliminaba un agregado hecho por el "Proyecto II" que aclaraba, en lo referido al hábito eclesiástico, que se trataba del "actualmente usado por el clero secular o regular católico”. Este artículo regulaba dos temas diversos, el primero de los cuales

18 "Proyecto I", artículo 4: "Los obispo y el clero podrán comunicarse libre y directamente con la Santa Sede, y en la misma forma podrán los obispos comunicarse con el clero $y$ fieles de su dependencia, y publicar sus pastorales y ordenanzas".

19 "Proyecto II", artículo 4: "El gobierno de Chile asegura a la Iglesia y a los organismos que de ella dependen el libre ejercicio de su poder espiritual y de su jurisdicción eclesiástica, lo mismo que la libre administración de sus bienes y negocios, conforme al derecho canónico en cuanto no se oponga a las leyes chilenas".

20 "Proyecto I", artículo 5; "Proyecto II", artículo 5: "Las autoridades chilenas apoyarán la ejecución de las decisiones y de los decretos eclesiásticos en caso de prohibición a un eclesiástico del ejercicio del ministerio sacerdotal en locales públicos destinados al culto o del uso del hábito eclesiástico, de resguardo del orden en actos o manifestaciones religiosas en lugares públicos y en las otras circunstancias en que prescriban o permitan tal apoyo las leyes chilenas". 
era el apoyo estatal a la ejecución de decisiones eclesiásticas sobre dos materias propiamente eclesiásticas: la destitución de un eclesiástico y la prohibición de uso de traje eclesiástico. En este aspecto, el artículo recogía una vieja práctica regalista cual era el apoyo del brazo secular para la ejecución de decisiones eclesiásticas. Se trataba, pues, de una materia que, siendo explicable en otras circunstancias históricas, se ha transformado en una figura anacrónica por lo que no aparece recogida en los concordatos posteriores al Concilio Vaticano II (1965) con la sola excepción del concordato con Colombia (1973, artículos XXI, XXII), normas, éstas, que, además de haber sido inoperantes, posteriormente la Corte Constitucional colombiana ha declarado inconstitucionales ${ }^{21}$.

En la segunda parte de este artículo se aseguraba el resguardo del orden en actos o manifestaciones religiosas en lugares públicos y en las otras circunstancias en que tal apoyo lo prescribían o permitían las leyes chilenas. Se trataba de una materia diversa, pues entraba en las obligaciones que corresponden al Estado de velar por el orden en los actos que se desarrollan en los lugares públicos, cualquiera sea la naturaleza de los mismos. Es por lo que esta obligación aparece en concordatos recientes como el de Lituania (2000, sobre aspectos jurídicos artículo $7 \mathrm{~N}^{\circ}$ 6) según el cual los actos religiosos realizados fuera de los templos como procesiones o peregrinaciones han de ser notificadas por la autoridad religiosa a la autoridad estatal, para que se garantice el orden público y la seguridad, norma que en términos similares se encuentra en el acuerdo con Bosnia-Herzegovina (2006, artículo 7.5).

\section{Artículo 7}

"Se aplicarán a los sueldos, gratificaciones y pensiones, que percibieren los funcionarios eclesiásticos como tales, las disposiciones legales que estén en vigor sobre embargo de sueldos, gratificaciones y pensiones que pagan el Estado y las municipalidades".

Se recogía el artículo 6 de los dos proyectos del gobierno ${ }^{22}$ sin introducirle ninguna modificación. Este artículo, que reproducía el artículo 5 de los concordatos de Polonia (1925) y Lituania (1927), se hacía eco del viejo privilegio de competencia que podía remontarse a las decretales de Gregorio IX (1234), que pretendía evitar que parte de los bienes de un clérigo deudor fueran ejecutados, a fin de dejarle lo necesario para su sustento. La manera

${ }^{21}$ Prieto, Vicente, cit. (n. 13), p. 171.

22 "Proyectos I y II", artículo 6: "Se aplicarán a los sueldos, gratificaciones y pensiones que percibieren los funcionarios eclesiásticos como tales las disposiciones legales que estén en vigor sobre embargo de sueldos, gratificaciones y pensiones que pagan el Estado y las municipalidades". 
que se utilizó en los concordatos del siglo XX para regular ese privilegio fue asimilar los bienes de los clérigos a los bienes de los funcionarios del Estado y fueron los dos concordatos mencionados los primeros en consagrarlo en el siglo XX. Pero ¿puede la jurisdicción civil reservar un tratamiento especial a una categoría de ciudadanos para preservar su dignidad? Y si así fuera, tratándose de los clérigos ¿el favor es en razón de su estado particular? Cualquiera sea la respuesta, lo cierto es que a los concordatos señalados hay que agregar los celebrados con Italia (1929, artículo 6), Austria (1933, artículo XVII), Yugoslavia (1935, artículo XVI inciso 5º , y España (1953, artículo $16 \S$ $6)$, pero los concordatos y acuerdos post-conciliares han ignorado pura y simplemente el privilegio de competencia.

\section{Artículo 8}

"[Inciso $\left.1^{\circ}\right]$ Los sacerdotes seculares y regulares, los religiosos profesos, los alumnos de la sección eclesiástica de los seminarios y los de los noviciados estarán exentos del servicio militar obligatorio, exceptuando el caso de reclutamiento general.

“[Inciso $2^{\circ}$ ] En este caso, y cuando se enrolaren voluntariamente, serán llamados a ejercer su ministerio en las filas o destinados a los servicios sanitarios o de administración.

“[Inciso $3^{\circ}$ ] Aún en caso de reclutamiento general, quedarán exentos del servicio militar los párrocos, los sacerdotes seculares y regulares en cura de almas o en servicio de iglesias, y el personal eclesiástico indispensable para el funcionamiento de las curias diocesanas, de los seminarios, y de los colegios católicos.

"[Inciso $4^{\circ}$ ] Los eclesiásticos estarán también exentos de cualquiera obligación de ejercer funciones o cargos civiles incompatibles con la vocación sacerdotal, en conformidad con el derecho canónico".

Este artículo recogía en los dos primeros incisos el artículo 8 del "Proyecto I", que pasó a ser, textualmente, el artículo 7 del "Proyecto II", concebidos ambos en un solo inciso ${ }^{23}$; el inciso $3^{\circ}$ es nuevo, y el inciso $4^{\circ}$ incorpora el que era el artículo 9 de "Proyecto I" que pasó, sin cambio alguno, a ser el artículo 8 del "Proyecto II" del gobierno ${ }^{24}$. De esta manera, este artículo 8

23 "Proyecto I", artículo 8; "Proyecto II", artículo 7: "Los eclesiásticos que ya hubieren sido ordenados, los religiosos que y a hubieren hecho votos, los alumnos de los seminarios y los novicios que hubieren ingresado a los seminarios o noviciados antes de una declaración de guerra, estarán exentos del servicio militar obligatorio, exceptuando el caso de reclutamiento general. En este último caso y cuando se enrolaren voluntariamente, los miembros del clero y religioso, especialmente los sacerdotes ordenados, serán destinados de preferencia a ejercer su ministerio en las fllas o a los servicios sanitarios o de administración".

24 "Proyecto I", artículo 9; "Proyecto II", artículo 8: "Los eclesiásticos estarán exen- 
del proyecto del nuncio regulaba dos materias diferentes: el servicio militar de los eclesiásticos y la exención de funciones o cargos civiles incompatibles con la vocación sacerdotal.

En lo referido al servicio militar, el Código de Derecho Canónico de 1917 disponía que "todos los clérigos están exentos del servicio militar" (canon 121), norma que era aplicable a los religiosos, incluso los legos y los novicios (canon 614), por lo que el proyecto recogía la disciplina canónica vigente. En el plano concordatario el tema se presenta con cierta complejidad ${ }^{25}$. Después de la primera Guerra Mundial el tema fue abordado con cierto detalle, distinguiéndose los tiempos de paz y de movilización general, de lo que se hacían eco los proyectos del gobierno chileno que tomaban como modelos los concordatos de Polonia (1925, artículo 5) y Lituania (1927, artículo 5), normas que fueron retomadas prácticamente en todos los concordatos posteriores. Un cambio radical se produjo en el acuerdo con España sobre la asistencia a las Fuerzas Armadas (1979) puesto que "los clérigos y religiosos están sujetos a las disposiciones generales de la ley sobre servicio militar" (artículo V inciso $1^{\circ}$ ), si bien a los presbíteros se les "podrán encomendar funciones especificas de su ministerio" (artículo V,2) y a los presbíteros a quienes no se les encomienden tales funciones y a los diáconos y religiosos profesos no sacerdotes "seles asignarán misiones que no sean incompatibles con su estado, de conformidad con el derecho canónico" (artículo V. 3). Ha sido, a decir verdad, una feliz conciliación de dos principios aparentemente contrapuestos, por una parte la norma civil de igualdad de todos ante la ley y, por otra, la incompatibilidad de los eclesiásticos de portar armas. Excepcionalmente, los obispos quedan exentos del servicio militar en todo caso, pero ello no en virtud de su calidad personal, sino "a fin de asegurar la debida atención pastoral del pueblo" (artículo VI inciso $1^{\circ}$ ), es decir, en atención a la necesidad de preservar un servicio social. Y en caso de movilización general, "se procurará asegurar la asistencia parroquial proporcional a la población civil" (artículo VI inciso $2^{\circ}$ ).

El acuerdo con Italia (1984) fue más sutil pues introduce la novedad de que los clérigos y religiosos profesos no quedan automáticamente exentos del servicio militar, sino que tienen la facultad de obtener a petición de ellos, ser exonerados del servicio militar o asignados al servicio civil sustitutivo (artículo 4. 1). Los estudiantes de teología o los novicios de institutos de vida consagrada y de sociedades de vida apostólica, pueden hacer uso del reenvío del servicio militar acordado a los estudiantes de las universidades italianas (artículo 4.3). Y en caso de movilización general, los eclesiásticos con cura

tos de ejercer funciones o encargos incompatibles con el ministerio sacerdotal, como el de administrar justicia en asuntos ajenos al fuero eclesiástico".

${ }^{25}$ Minnerath, Roland, L'Église catholique face aux États. Deux siècles de pratique concordataire 1801-2010 (Paris, Les Éditions du Cerf, 2012), pp. 279-287. 
de almas no serán movilizados, en tanto que los otros serán asignados al servicio religioso de la tropa o a los servicios de enfermería (artículo 4. 2). En suma, los eclesiásticos y religiosos italianos, en la práctica, continuarán usando de la exención del servicio militar, pero no en atención a un derecho inherente a su calidad personal.

La exención del servicio militar de clérigos y religiosos sigue estando presente en los concordatos más recientes firmados con países de la Europa central y países bálticos, como Polonia (1993, artículo 16) y Letonia (2000, artículo 26). En el caso de la República Eslovaca (2000, artículo 14. 2;2002, asistencia religiosa a las Fuerzas Armadas, artículo 6), el servicio militar es obligatorio, si bien "los sacerdotes, los diáconos, los religiosos, los seminaristasy los novicios tienen el derecho de desarrollar el servicio militar obligatorio con un servicio espiritual en las Fuerzas Armadas". Y en el acuerdo con la República Checa (2002, artículo 7) se dispensa del servicio militar a las personas que hace valer una objeción de conciencia o una convicción religiosa, situación parecida a la del concordato portugués (2004, artículo 17.4 ), pero ya no se trata de una exención en beneficio particular los clérigos, sino de un derecho general que puede ser invocado por cualquier ciudadano, incluso no católico.

El inciso final del artículo 8 del proyecto del nuncio regulaba la exención de los eclesiásticos de la obligación de ejercer funciones o cargos civiles incompatibles con la vocación sacerdotal, en conformidad con el derecho canónico, dando una nueva redacción al artículo 9 de los proyectos del gobierno chileno. El Código de Derecho Canónico de 1917 en el mismo canon 121 que en su primera parte afirmaba la exención del servicio militar de los clérigos, en la continuación del mismo afirmaba de manera general su exclusión de "los cargosy oficios públicos civiles ajenos al estado clerical"; como ambas exclusiones estaban tratadas en el mismo canon, pudo esta sistemática influir para que el nuncio incorporara ambas exenciones en un mismo artículo. Más adelante el código canónico les prohibía hacer de escribanos o de notarios ni admitir cargos públicos que llevasen consigo ejercicio de jurisdicción o administración laical (canon $139 \$ 2$ ), y la función de administración de la justicia que era expresamente excluida en los "Proyectos I y II".

Entre los concordatos del siglo XX anteriores al Concilio Vaticano II esta exención se encontraba formulada en términos generales en los concordatos de Lituania (1927, artículo 5) que sirvió de modelo a los proyectos gubernamentales chilenos, de España (1953, artículo 14) y República Dominicana (1954, artículo $11 \S 3$ ). Otros entraban a precisar las funciones exentas: jurados y miembros de tribunales (Letonia 1922, artículo IX; Polonia 1925, artículo V); jurado (Italia 1929, artículo 4); jurado y regidor municipal (Austria 1933, artículo XIX); regidor municipal, jurado, miembro de comisiones de impuestos y de tribunales de finanza (Alemania 1933, 
artículo 6); jurado y comisionado de impuestos (Portugal 1940, artículo XIII). Después del Concilio Vaticano II Colombia mantuvo la exención (1973, artículo XVIII), norma que ha sido declarada constitucional ${ }^{26}$, pero España (1979) e Italia (1984) simplemente la abolieron. Más recientemente, en cambio, Portugal (2004, artículo 6) dispensa a los eclesiásticos de la función de jurado, de miembro de los tribunales o de otros cargos de la misma naturaleza considerados por el derecho canónico como incompatibles con el estado eclesiástico.

\section{Artículo 9}

"El Gobierno de Chile asegura la inmunidad de las iglesias, capillas, conventos y cementerios católicos, en cuanto lo permitan las exigencias de la seguridad pública”.

Recogía el artículo 10 del "Proyecto I" que pasó a ser el artículo 9 del Proyecto $\mathrm{II}^{27}$, eliminando, el proyecto del nuncio, la limitación de "hasta donde lo permitan el respeto de la ley chilena" que aparecía en los dos proyectos gubernamentales, pero conservando "las exigencias de la seguridad pública”. Diez años antes de estos proyectos, el Código de Derecho Canónico había afirmado que "los lugares sagrados están exentos de la jurisdicción de la autoridad civil, y la autoridad eclesiástica legitima ejerce en ellos libremente su jurisdicción" (canon 1160), lo que trajo como consecuencia que, dejándose de lado el silencio que sobre esta materia había caracterizado a los concordatos decimonónicos, esta inmunidad empezara a aparecer en los concordatos celebrados después de la primera Guerra Mundial, en los años inmediatamente anteriores a los proyectos chilenos, en concreto Letonia (1922, artículo XV, XX inciso 2), Polonia (1925, artículo VI) y Lituania (1927, artículo VI). Después del Concilio, el acuerdo español acerca de cuestiones jurídicas de 1979 fue el único en reconocer esta inmunidad, la que se extendió a los archivos, registros y otros documentos pertenecientes a la Conferencia Episcopal española, de las curias episcopales, de las curias de los superiores mayores de órdenes o congregaciones religiosas, de parroquias y de otras instituciones o entidades eclesiásticas (artículo I. 5, 6). Esta inviolabilidad ha reaparecido con fuerza en los concordatos celebrados desde 1996 con países bálticos y centroeuropeos después de la caída del comunismo, en concreto Croacia (1996 sobre cuestiones jurídicas, artículo 7,2), siendo el obispo quien decide "sobre la necesidad de construir edificios eclesiásticos y

${ }^{26}$ Prieto, Vicente, cit. (n. 13), pp. 171-173.

27 "Proyecto I", artículo 10; "Proyecto II", artículo 9: "El gobierno de Chile asegura la inmunidad de las iglesias, capillas, conventos y cementerios católicos hasta donde la permitan el respeto de la ley chilena y las exigencias de la seguridad pública". 
de escoger el lugar", actuando en esto de acuerdo con las autoridades croatas (artículo 11.2); República Eslovaca (2000, artículo 5), que define lo que se entiende por inviolabilidad de los lugares sagrados: "Con la inviolabilidad de los lugares sagrados, las altas partes entienden la protección de estos lugares, que consiste en impedir usarlos para otros fines que no sean conformes al derecho canónico, e impedir la violación de la propia dignidad de ellos" (inciso $2^{\circ}$ ), si bien, por graves motivos y con el consentimiento de la Iglesia católica un lugar sagrado puede ser utilizado para otra finalidad que no esté en contraste con la sacralidad del lugar (inciso $3^{\circ}$ ); Lituania (2000 sobre aspectos jurídicos, artículo 7); Letonia (2000, artículo 6); Bosnia Herzegovina (2006, artículo 7). Pero esta inviolabilidad no ha quedado encerrada en esta parte del viejo continente sino que aparece también en los concordatos con Gabón (1997, artículo 6), Portugal (2004, artículo 7), el principado de Andorra (2008, artículo V) y Brasil (2008, artículo 7) el que, además de los lugares, protege sus liturgias, símbolos, imágenes y objetos cultuales contra toda forma de violación, desprecio y uso ilegítimo.

Artículo 10

"El Ejército de Chile gozará de todas las exenciones, que, según las prescripciones del derecho canónico, otorga la Santa Sede a otros ejércitos. Los capellanes castrenses, en su actuación referente a los militares y sus familias, tendrán los derechos inherentes a la cura de almas, y ejercerán las funciones de su ministerio bajo la jurisdicción de un vicario general castrense, que tendrá el derecho de escogerlos. En lo que se refiere al servicio, este clero estará sometido a las autoridades militares".

Repetía, con ligeros cambios de redacción en el paso final, el artículo 11 del "Proyecto I" y artículo 10 del "Proyecto II"28, pero omitiendo en la última frase el adjetivo "militar" que en los proyectos gubernamentales calificaba a la palabra "servicio", omisión poco feliz porque podía dificultar la comprensión de dicha frase. Se regulaba la asistencia religiosa a las Fuerzas Armadas que en Chile, cuando se redactaban estos proyectos, se extendía al ejército y la armada, y estaba entregada al vicariato castrense, creado por la ley 2.463 ,

28 "Proyecto I", artículo 11; "Proyecto II", artículo 10: "El Ejército de Chile gozará de todas las exenciones que según las prescripciones del derecho canónico otorga la Santa Sede a otros ejércitos. Los capellanes castrenses, en su actuación referente a los militares y sus familias, tendrán los derechos inherentes a la cura de almas y ejercerán las funciones de su ministerio bajo la jurisdicción de un vicario general castrense que tendrá el derecho de escogerlos. La Santa Sede permite que este clero, en lo que se refiere al servicio militar, esté sometido a las autoridades militares". 
después que Pío X, mediante el breve In hac beatissiimi Petri cathedra, de 3 de mayo de $1910^{29}$, creara el vicariato castrense para Chile.

Se trata de una norma permanentemente presente en el derecho concordatario moderno, ya incorporada en un concordato general, como sucede con Colombia (1973, artículo XVII) y Perú (1980, artículo XI-XVII), ya en acuerdos específicos sobre asistencia religiosa a las Fuerzas Armadas, modalidad utilizada con preferencia en América Latina después del Concilio Vaticano II, como sucede con El Salvador (1968), Ecuador (1978), Bolivia (1986), Brasil (1989), República Dominicana (1990), Argentina (1992), Venezuela (1994), Paraguay (2002).

\section{Artículo 11}

"[Inc. $1^{\circ}$ Los matrimonios celebrados en conformidad con la ley chilena por ministros del culto católico, producirán efectos civiles.

"[Inc. $\left.2^{\circ}\right]$ Los bautismos administrados por dichos ministros producirán efectos iguales a las inscripciones de nacimientos efectuadas en el registro civil, siempre que sean notificados al oficial de la circunscripción respectiva.

"[Inc. $\left.3^{\circ}\right]$ Los ministros de culto católico tendrán la obligación de notificar al respectivo oficial del registro civil los dichos matrimonios y los bautismos, en el plazo y en la forma que será determinada por el gobierno de Chile, de acuerdo con la competente autoridad eclesiástica".

Se recogía en este artículo, notablemente reformados, el artículo 12 del "Proyecto I"30, y el artículo 11 del "Proyecto II" ${ }^{1}$. Se trata de la materia que en el decurso de estos tres proyectos sufrió más modificaciones. En el primero de los proyectos se disponía que los sacerdotes que bendijeren en Chile matrimonios celebrados conforme al rito católico, debían asegurar "por todos los medios a su alcance" la celebración del matrimonio civil por los contrayentes, debiendo los ordinarios dictar las providencias eficaces que velaran por su cabal observación. El proyecto II, con un texto más breve, daba un paso decidido en pro de la precedencia del matrimonio civil respecto del

${ }^{29}$ Pío X, Breve 'In hac beatissimi Petri cathedra' (3 de mayo de 1910), en Acta Apostolicae Sedis, 2 (1910), pp. 501-503. En latín y en castellano en GonzÁlez ErRÁzuRIZ, Juan Ignacio, Iglesia y Fuerzas Armadas. Estudio canónico y jurídico sobre la asistencia espiritual a las Fuerzas Armadas en Chile (Santiago de Chile, 1994), pp. 273-277.

30 "Proyecto I", artículo 12: "Los sacerdotes que bendijeren en Chile matrimonios celebrados conforme al rito católico asegurarán por todos los medios a su alcance la celebración por los contrayentes de matrimonio civil conforme a la ley chilena, y los ordinarios dictarán en igual sentido providencias eficaces y velarán por su cabal observación”.

31 "Proyecto II", artículo 11: "Los sacerdotes que bendijeren en Chile matrimonios celebrados conforme al rito católico, lo harán una vez presentado el certificado que acredite la celebración del matrimonio civil". 
canónico, disponiendo que "los sacerdotes que bendijeren en Chile matrimonios celebrados conforme al rito católico, lo harán una vez presentado el certificado que acredite la celebración del matrimonio civil".

En la carta con la que el nuncio enviaba los "Proyecto II y III" a Roma, explicaba al secretario de Estado que, en lo referido al matrimonio, quedaba claro en su proyecto que los matrimonios canónicos producirían efectos civiles cuando dicho matrimonio fuere celebrado conforme a las leyes chilenas, es decir, cuando los contrayentes reunieren los requisitos queridos por la ley; por su parte, el bautismo producía los mismos efectos que la inscripción de nacimiento sólo una vez notificado el respectivo oficial civil; y la obligación de notificar los bautismos y matrimonios se establecía como una manera de colaborar con el Estado en el mejoramiento del servicio de estadísticas demográficas. Concluía el nuncio con una valoración final de todo el artículo, manifestando que la solución le parecía "verdaderamente genial", en cuanto conciliaba la razonable exigencia del Estado con la absoluta libertad de la Iglesia en la administración de dichos sacramentos, además que, reconociendo efectos civiles al matrimonio religioso, que en Chile constituían la casi totalidad, este artículo ofrecía una base para protestar, en nombre del concordato, contra un eventual proyecto de divorcio.

Una mirada a los concordatos celebrados entre la Santa Sede con países latinoamericanos durante el siglo XIX ${ }^{32}$, permite advertir la total aceptación de la jurisdicción eclesiástica sobre el matrimonio, si bien ellos la reconocían más por su silencio que por declaraciones expresas, habida consideración que todos ellos eran Estados confesionales que consideraban a la religión católica la religión oficial ${ }^{33}$. Fueron dos concordatos firmados por León XIII, con Montenegro (1886, artículo 9) y con Colombia (1887, artículo 17) los que innovaron en esta materia introduciendo el reconocimiento civil del matrimonio canónico, siendo el concordato colombiano el primero en mencionar un procedimiento de transcripción, que, a partir de 1929, fue incorporado en casi todos los concordatos que hacían mención al matrimonio ${ }^{34}$. Un reconocimiento civil del matrimonio canónico hacía el concordato con Lituania (1927, artículo XV) que sirvió de modelo a las autoridades chilenas para la redacción de estos proyectos, pero que en esta materia no lo siguió. A decir verdad, el reconocimiento del matrimonio por el derecho de los Estados es una materia que depende directamente de la situación interna de cada país y de las vicisitudes de las relaciones del poder temporal con el espiritual.

Después del Concilio Vaticano II (1965), se ha conservado en no pocos

\footnotetext{
${ }^{32}$ Salinas Araneda, Carlos, Un primer, cit. (n. 13), pp. 215-254.

${ }^{33}$ Minnerath, Roland, cit. (n. 25), p. 485.

${ }^{34}$ Ibíd., p. 490.
} 
acuerdos el reconocimiento del matrimonio canónico, manteniéndose el procedimiento de transcripción pero ahora sometido a ciertas condiciones restrictivas relativas a la ausencia de impedimentos civiles, con lo que el automatismo de la producción de efectos civiles de los primeros concordatos se ha ido limitando, advirtiéndose en los Estados una intervención más activa que el simple reconocimiento civil del matrimonio canónico. Así, el concordato con Polonia (1993, artículo 10) reconoce civilmente el matrimonio canónico "desde el momento de la celebración" con tal que: i) entre los esposos no exista impedimentos previstos por la legislación polaca; ii) que con ocasión de la celebración matrimonial los esposos manifiesten de común acuerdo su voluntad de que el matrimonio produzca efectos civiles; iii) se notifique al registro civil, dentro de los cinco días, la celebración del matrimonio, plazo que se puede ampliar " a causa de fuerza mayor". En este concordato, además, se establece que "la preparación del matrimonio canónico comprende la instrucción de los futuros esposos sobre la indisolubilidad del matrimonio canónico y sobre las normas del derecho polaco concernientes a los efectos del matrimonio" (artículo 10.2). En términos similares se pronuncia el acuerdo con Croacia sobre cuestiones jurídicas (1996, artículo 13). El acuerdo con Estonia (1999, artículo 8) dispone que los matrimonios canónicos producirán efectos civiles previo registro y a los cuales se haya otorgado por el registro civil un certificado de matrimonio, pero silencia desde cuándo se producen dichos efectos, a diferencia de los acuerdos con Letonia (2000, artículo 8) y Lituania (2000 sobre aspectos jurídicos, artículo 13), que fijan esos efectos "desde el momento de la celebración religiosa". Desde el mismo momento producirán efectos civiles los matrimonios canónicos celebrados en Brasil (2008, artículo 12) y en Portugal (2004, artículo 13-16), pero en éste siempre que el registro se haga dentro de los siete días de la celebración, pues de no respetarse ese plazo, los efectos civiles empezarán a producirse desde la fecha de la inscripción.

El acuerdo con Gabón (1997, artículo 12) no reconoce civilmente el matrimonio canónico, pero, "en razón del valor espiritual, moral y educativo del matrimonio canónico, la República del Gabón le reconoce una importancia particular en la construcción de la familia en el seno de la nación", por lo que la República de Gabón se empeña a trabajar de concierto con la Santa Sede "para un eventual reconocimiento del matrimonio canónico y de sus efectos civiles".

Artículo 12

"Ninguna jurisdicción eclesiástica del territorio de Chile dependerá de un obispo que tenga su residencia fuera de las fronteras de la República”.

El artículo 14 del "Proyecto I" disponía que “ninguna parte del territorio 
de Chile" dependería de un obispo residente fuera de las fronteras chilenas, expresión, más bien geográfica, que fue sustituida en el "Proyecto II" por la de "ninguna jurisdicción eclesiástica del territorio de Chile", que fue la que recogió textualmente el "Proyecto III". Si nos situamos en la época en que se redactan estos proyectos, mayo de 1928, en que aún estaba sin resolverse la situación de las provincias de Tacna y Arica, sometidas políticamente a Chile pero eclesiásticamente al obispo de Arequipa, este artículo venía a solucionar un problema no menor que se había suscitado en dichas provincias ${ }^{35}$.

El nuncio, en la carta con la que envió a Roma el contraproyecto elaborado por él, hacía presente que entre las concesiones requeridas por el gobierno estaba "la sustracción de los organismos eclesiásticos de la jurisdicción de los obispos residentes fuera de las fronteras de la República". Al respecto, ilustraba a Roma sobre las dificultades que presentaba el artículo 12, cuya aplicación sustraería de la jurisdicción del ordinario de Arequipa los territorios contestados de Tacna y Arica. "El gobierno le otorga, naturalmente, enorme importancia, y no temo exagerar afirmando que está en éste y en el artículo 14 el verdadero motivo de la simpatía con la que han sido acogidos los pasos dados por mí para alcanzar la conclusión de un concordato"36. Teniendo presente que los territorios mencionados se encontraban de hecho bajo el dominio de la República de Chile, el nuncio sugería, en forma de pregunta, una solución que había sido avanzada por Chile con anterioridad: “¿se podría nombrar provisoriamente un administrador apostólico de Tacna y Arica, dejando sin prejuzgar la cuestión pendiente entre los dos Estados, como se hizo en Fiume?"37

Tal medida, entendía el nuncio, sólo modificaría la situación jurídica de ambas provincia, que se encontraban, de hecho, bajo la jurisdicción del vicario castrense chileno, y mejoraría sensiblemente la situación religiosa

${ }^{35}$ Un testimonio de la época puede leerse en El conflicto eclesiástico de Tacna. Antecedentes y documentos oficiales, en La Revista Católica, 240 (1911), pp. 84-90.

${ }^{36} \mathrm{El}$ artículo 14 del "Proyecto II" regulaba el nombramiento de arzobispos y obispos y en él se concedía al gobierno la facultad de oponer objeciones al candidato que había escogido la Santa Sede, la que se obligaba a dar a conocer su nombre al gobierno antes de su nombramiento.

${ }^{37}$ El puerto de Fiume -actual Rijeka, en Croacia- se encuentra en la costa del Mar Adriático y, después de la primera Guerra Mundial, fue disputado entre Italia y Yugoslavia. En 1919 un ejército italiano, al frente del cual estaba el poeta italiano Gabriele D’Annunzio, ocupó la ciudad estableciéndola como Estado soberano desde 1920 a 1924. Con el ascenso de Mussolini al poder, tras el golpe de 1922, el Estado libre de Fiume fue ocupado por las tropas fascistas y dos años más tarde anexionado a Italia. El mismo año 1920 la Santa Sede erigió una administración apostólica, con el nombre latino de Fluminensis, la que, una vez que Fiume fue incorporado a Italia, fue erigida en obispado, el 25 de abril de 1925. Actualmente es la arquidiócesis de Rijeka, en Croacia. 
que dejaba no poco que desear, ya que los elementos peruanos, mirando a los capellanes militares como "propagandistas asalariados del chilenismo", se habían ido progresivamente alejando de la Iglesia, con grave daño para la fe y las costumbres. No cabía dudas al nuncio que una medida como la propuesta iba a encontrar obstáculos por parte del gobierno peruano, pero, si ese era el precio necesario de un acuerdo con la Moneda, valía la pena tentar todas las vías de la persuasión para superarlas, en vista de las grandes ventajas que un concordato como el que se proyectaba, aseguraría a la Iglesia. Sobre la base de lo anterior, el nuncio conservaba, sin introducir modificación alguna, el mismo texto propuesto por el gobierno en el "Proyecto II", si bien, la sustitución de la expresión "ninguna parte del territorio de Chile" que era, por lo demás, la que utilizaba el concordato con Lituania que servía de modelo, por la de "ninguna jurisdicción eclesiástica del territorio de Chile", no era inocua. Parece claro que este artículo venía a ofrecer una solución al conflicto suscitado en los territorios ocupados por el ejército chileno durante la Guerra del Pacífico, problema que poco después de la redacción de estos proyectos quedó solucionado, mediante el “Tratado de Lima”, celebrado en dicha ciudad el 3 de junio de 1929 en el que se estableció que la provincia de Tacna se reincorporaba a Perú permaneciendo la de Arica en poder de Chile.

Pero esta cláusula se encontraba no sólo en el concordato con Lituania (1927, artículo IX), que había servido de modelo, sino también en los de Polonia (1925, artículo IX) y Rumanía (1927, artículo III), es decir, Estados que deseaban reafirmar su soberanía, lo que explica su inclusión en ellos. Pero una simple mirada a los acuerdos vigentes, permite encontrarla reproducida en no poco de ellos, tanto en territorios europeos como España (1979 sobre cuestiones jurídicas, artículo I. 2 inciso $3^{\circ}$ ), Italia (1984, artículo 3. 1), Polonia (1993, artículo 6.2), Eslovenia (2001, artículo 4 inciso $2^{\circ}$ ), Portugal (2004, artículo 9.5) como latinoamericanos: Venezuela (1964, artículo V inciso $2^{\circ}$ ), Perú (1980, artículo V) y Brasil (2008, artículo 4).

\section{Artículo 13}

"[Inc. $1^{\circ}$ ] La creación y modificación de los beneficios eclesiásticos y de las comunidades religiosas, como también de sus casas y establecimientos, dependerá de las autoridades eclesiásticas competentes.

"[Inc. 2'] Para el establecimiento en Chile de nuevas comunidades religiosas se pondrá en conocimiento del gobierno el auto de erección o autorización del ordinario".

Se recogía parcialmente y en forma reducida el artículo 15 del "Proyecto 
I"38 reproducido textualmente en el artículo 13 del "Proyecto II". El inciso $1^{\circ}$ de ambas normas se traslada textualmente del primero a los otros dos proyectos. El inciso $2^{\circ}$ del proyecto del nuncio, en cambio, sustituyó los incisos $2^{\circ}$ y $3^{\circ}$ del "Proyecto I" trasladados textualmente al "Proyecto II". Según el inciso $2^{\circ}$ de aquéllos, para el establecimiento en Chile de nuevas comunidades religiosas se requería autorización del gobierno; según el inciso $3^{\circ} \mathrm{de}$ los mismos, los extranjeros no podrían desempeñar los cargos de superiores de provincias de las comunidades religiosas de varones establecidas en Chile sin haber obtenido previamente autorización del gobierno. El proyecto del nuncio dejaba de lado dichas exigencias neo-regalistas y la sustituía por la mera notificación del auto de erección o de autorización del ordinario, y eliminaba derechamente la limitación referida a los extranjeros, limitación que volveremos a encontrar en otro artículo.

El inciso primero reconocía el derecho de la Iglesia para la creación y modificación de beneficios eclesiásticos y comunidades religiosas con sus casas y establecimientos, reconocimiento que, con limitaciones, se consagra en algunos acuerdos posteriores al Concilio Vaticano II, limitaciones que, con el paso del tiempo, han ido desapareciendo. En lo que se refiere a la libertad de la Iglesia para organizarse territorialmente, para situarnos entre los países latinoamericanos, Venezuela (1964) presenta las mayores exigencias, pues para la erección de nuevas diócesis y modificación de sus límites, si bien reconoce que ello corresponde a la Santa Sede, deberá hacerlo "previo acuerdo con el gobierno" (artículo V inciso $1^{\circ}$ ); en cambio, en lo referido a las parroquias, la iniciativa corresponde libremente a la autoridad eclesiástica, "las cuales comunicarán a la primera autoridad civil de la jurisdicción la erección y los limites de las nuevas parroquias asi como los cambios de limites de las parroquias ya existentes" (artículo X). En Argentina (1966) hay también una intervención del gobierno en la erección de nuevas diócesis u otros cambios de circunscripciones diocesanas, pues, siendo la iniciativa de la Santa Sede, "comunicará confidencialmente al gobierno sus intenciones [...] a fin de conocer si éste tiene observaciones legítimas" (artículo II inciso 2º). En Perú (1980) en cambio, la libertad de la Iglesia es mayor, pues sólo tiene que notificar al gobierno la creación de cualquier diócesis o jurisdicción eclesiástica, a fin de que puedan gozar de personalidad jurídica de carácter público (artículo VI). El cambio se va a producir en los acuerdos con España sobre cuestiones

38 "Proyecto I", artículo 15; "Proyecto II", artículo 13: “[Inc. 1] La creación y modificación de los beneficios eclesiásticos, y de las comunidades religiosas, como también de sus casas y establecimientos, dependerá de las autoridades eclesiásticas competentes. [Inc. $2^{\circ}$ ] Para el establecimiento en Chile de nuevas comunidades religiosas se requerirá autorización del gobierno. [Inc. $3^{\circ}$ ] Los extranjeros no podrán desempeñar los cargos de superiores de provincias de las comunidades religiosas de varones establecidas en Chile sin haber obtenido previamente autorización del Gobierno". 
jurídicas (1979, artículo I. 2 inciso $1^{\circ}$ ) e Italia (1984, artículo 3. 1), de manera que en los acuerdos posteriores la tónica ha sido la libertad de la Iglesia en esta materia como puede verse en el concordato con Gabón (1997, artículo $3 \$ 1)$ debiendo tan sólo "informar" a las autoridades gabonesas, al igual que en el concordato Letonia (2000, artículo 2.3), Eslovaquia (2000, artículo 3. 1-2), Portugal (2004, artículo 9), Bosnia-Herzegovina (2006, artículo 2.3). En cambio en los acuerdos con Polonia (1993, artículo 6.1), Croacia (1996 sobre cuestiones jurídicas, artículo 5), Lituania (2000, artículo 5. 1), Eslovenia (artículo 4) o Brasil (2008, artículo $3 \$ 1)$ la libertad de la Iglesia es total.

En cuanto a la libertad para erigir congregaciones, los concordatos posteriores al Concilio Vaticano II no se han ocupado mayormente de ella ${ }^{39}$, pero los que lo hacen, reconocen la libertad de la iglesia en esta materia, como sucede con España (1979, artículo I. 2 inciso $2^{\circ}$ ) o con Croacia (1996 sobre cuestiones jurídicas, artículo 5).

\section{Artículo 14}

"[Inc. $1^{\circ}$ L La designación del arzobispo y de los obispos corresponde a la Santa Sede, la cual antes de nombrar al arzobispo, a los obispos diocesanos, a los coadjutores con derecho de sucesión y al vicario general castrense consultará al gobierno de la República, para cerciorarse de que éste no tiene objeciones de orden politico contra los candidatos.

"[Inc. $\left.2^{\circ}\right]$ El gobierno de Chile manifestará sus objeciones, si las tuviere, en el plazo de un mes desde la fecha de la consulta, y la Santa Sede las tomará en la debida cuenta, a menos que, efectuada una rigurosa encuesta, no le resulten infundadas. En este caso, y en el caso de que, transcurrido el dicho plazo, el gobierno no haya hecho observación alguna, la Santa Sede procederá al nombramiento".

Este artículo recogía el artículo 16 del "Proyecto I" 40 que pasó, con modificaciones, a ser el artículo 14 del "Proyecto II"¹. El artículo 16 del "Proyecto I" correspondía, con leves variantes de redacción, al inciso $1^{\circ}$

${ }^{39}$ Minnerath, Roland, cit. (n. 25), pp. 337-338.

40 "Proyecto I", artículo 16: "La designación de arzobispo y obispo corresponde a la Santa Sede. Su Santidad se dignará consultar al presidente de la República antes de nombrar al arzobispo y a los obispos diocesanos, a los coadjutores con derecho de sucesión y al vicario general castrense, a fin de cerciorarse de que el presidente no tiene objeciones de carácter politico que oponer a los candidatos".

${ }_{41}$ "Proyecto II", artículo 14: "La designación de arzobispo y obispos corresponde a la Santa Sede. Su Santidad se dignará consultar al presidente de la República antes de nombrar al arzobispo y a los obispos diocesanos, a los coadjutores con derecho de sucesión, al vicario general castrense y sus capellanes, a fin de cerciorarse de que el presidente no tiene objeciones que oponer a los candidatos". 
del proyecto del nuncio. Pero al pasar al "Proyecto II" sufrió dos cambios: entre los nombramientos que había que consultar se agregaron los capellanes militares; y en cuanto a las objeciones que podía oponer el presidente de la República, se eliminó el adjetivo "políticas", con lo que se ampliaba la naturaleza de las mismas y la posibilidad de nuevas objeciones. Se trata de un cambio no menor que hay que situar en la tendencia neo-regalista del gobierno chileno que el proyecto del nuncio vuelve a encausar al calificar la naturaleza de las posibles objeciones como "políticas". El inciso segundo del "Proyecto III" no estaba en los proyectos chilenos, y con él se trataba de diseñar el procedimiento a seguir en cada caso. Hay que tener presente, sin embargo, que en la redacción de este inciso hay un "no" que sobra, pues las objeciones deberían tomarse en cuenta sólo cuando ellas eran fundadas, pues si eran infundadas, no cabía considerarlas.

En la carta con que el nuncio enviaba los "Proyecto II y III" al secretario de Estado, le manifestaba que no le parecía exagerado acordar al gobierno la facultad de oponer objeciones de orden políticas contra los candidatos, en atención a que lo mismo se estaba haciendo en los otros concordatos; por lo demás, entendía el diplomático, la facultad que se concedía, más que una concesión, era una "rémora providencial" a la injerencia que el gobierno intentaría ejercitar "perfas et nefas" en la provisión de las diócesis, en cuanto limitaba el campo de las objeciones y reservaba a la Santa Sede el derecho de apreciarlas inapelablemente.

Lo que el nuncio ha hecho, ha sido encausar el tema a los términos previstos en el concordato con Lituania que otorgaba al presidente de la República este derecho (artículo XI). Pero llama la atención que el nuncio no haya reparado en la situación particular producida en Chile a partir de 1925, año en que no sólo se crearon siete diócesis nuevas, como ha quedado dicho, sino que fueron designados sus obispos residentes, dos de los cuales eran de nueva creación ${ }^{42}$, sin que se hubiese consultado al gobierno. La práctica que a partir de ese momento empezó a llevar adelante la Santa Sede, fue notificar al gobierno el nombre del obispo ya designado, el día anterior a su publicación, como un mero gesto de cortesía a efectos de que el gobierno no se enterara del nombramiento por la prensa ${ }^{43}$. De hecho, ese ha sido el procedimiento que se ha seguido hasta el día de hoy, aceptado por el gobierno.

Si se mira la evolución que en esta materia ha ido experimentando el derecho concordatario, se advierte una clara evolución desde el derecho de presentación al derecho de formular objeciones políticas al candidato de la

${ }^{42}$ Rafael Lira Infante, primer obispo de Rancagua (1925-1938) y Miguel León Prado, primer obispo de Linares (1925- 1934).

${ }^{43}$ Salinas Araneda, Carlos, Un primer, cit. (n. 2), pp. 683-685. 
Santa Sede, para terminar en la pre-notificación por cortesía, fórmula utilizada en Chile desde 1925 y que se ha ido generalizando en los concordatos post conciliares más recientes: Italia (1984, artículo 3. 2), Polonia (1993, artículo 7.2-4), Croacia (1996 sobre cuestiones jurídicas, artículo 6. 1-3), Gabón (1997, artículo 7), Estonia (1998, artículo 5 inciso 2-3), Letonia (2000, artículo 5), Lituania (2000, artículo 6), Eslovaquia (2000, artículo 6), país en el que la autoridad estatal se obliga "a no expresar opiniones acerca de lapersona del interesado ni tomarposición sobre la decisión de la Santa Sede", Albania (2002, artículo 5), Portugal (2004, artículo 9.4). Hay dos acuerdos recientes que ni siquiera exigen la pre-notificación de cortesía, dejando plena libertad a la Iglesia en el nombramiento, traslado y remisión de los obispos, como son los de la República Checa (2002, artículo 6) y el acuerdo con Brasil (2008) que no aborda el tema porque siempre el nombramiento de los obispos ha sido libre.

\section{Artículo 15}

"Los ordinarios, los coadjutores con derecho de sucesión y el vicario general castrense, a que se refiere el articulo 14, antes de asumir sus funciones, prestarán ante el presidente de la República el juramento siguiente: "Ante Dios y sobre los Santos Evangelios juro y prometo como obispo fidelidad a la República de Chile, juro y prometo respetar con toda lealtad y hacer respetar por el clero de mi dependencia al gobierno establecido por la Constitución. Juro y prometo no participar en ningún acuerdo o acción que pueda atentar contra Chile y el orden público, no permitiré a mi clero participar en semejantes actos, velar por el bien y el interés del Estado y tratar de evitarle todo peligro que le amenace".

Recogía el artículo 17 del "Proyecto I", que pasó a ser, en los mismos términos, el artículo 15 del "Proyecto II" y que, sin modificaciones, es recibido por el proyecto del nuncio. Se recoge en esta cláusula concordataria el complemento del derecho de presentación, como es el juramento civil de los obispos, que mientras fue exigido en Chile, fue uno los temas conflictivos en las relaciones entre el Estado y la Iglesia. Pero, producida que fue la separación entre ambos poderes, espiritual y temporal, el juramento civil quedó de inmediato superado.

La libertad que el moderno derecho concordatario ha ido reconociendo a la Iglesia en la designación de los obispos, según comentaba con ocasión del artículo anterior, ha hecho que el juramento civil de los obispos haya desaparecido por completo.

\section{Artículo 16}

“[Inc.] La enseñanza de la religión católica figurará en los planes de estudio 
de los establecimientos de instrucción primaria, secundaria y especial del Estado, y será obligatoria en todos los cursos y para todos los alumnos, cuyos padres o guardadores no manifiesten por escrito al director del establecimiento respectivo el deseo de que no la reciban sus hijos o pupilos.

"[Inc.] Los textos y el programa de esta enseñanza serán fijados por la autoridad eclesiástica y los profesores serán nombrados de entre las personas autorizadaspor los ordinarios, que podrán retirar, cuando lo estimen necesario, la autorización ya dada a un profesor, quedando éste, por el hecho, inhabilitado para enseñar religión".

Se recogía, distribuido en dos incisos, lo que en un solo inciso regulaba el artículo 18 del "Proyecto I" y el artículo 16 del "Proyecto II"44. Se introducían en el proyecto del nuncio algunas modificaciones que explicitaban el contenido de los artículos anteriores, pues, mientras en ellos se disponía que la enseñanza religiosa figuraría en los planes de estudio "de todas las escuelas públicas de Chile", en este proyecto se hablaba "de establecimientos de instrucción primaria, secundaria y especial del Estado"; se cambiaba también la fórmula utilizada, pues, mientras en los proyectos del gobierno tan sólo se afirmaba que la enseñanza religiosa figuraría en los planes de estudio, ahora se agregaba que la misma sería "obligatoria en todos los cursos y para todos los alumnos" cuyos padres no manifestaren "por escrito" el deseo de no recibirla, exigencia formal que no aparecía en los proyectos anteriores; como se ve, el nuncio ha invertido los términos, pues mientras en los proyectos gubernamentales la enseñanza religiosa se daría a aquellos alumnos cuyos padres la solicitaren, en el proyecto del nuncio se da a todos, siendo los padres que no quieren que sus pupilos la reciban quienes tienen que pedirlo por escrito. $Y$ en el inciso segundo se agregaba la referencia a los textos y al programa de esta enseñanza que serían fijados por la autoridad eclesiástica, lo que estaba ausente en los proyectos del gobierno. Nada se decía, sin embargo, de la posibilidad de la Iglesia católica de establecer sus propios establecimientos de educación.

La enseñanza religiosa católica en la escuela pública es una materia que está presente en prácticamente todos los acuerdos post-conciliares en términos similares a los regulados internamente por el derecho chileno, esto

44 "Proyecto I", artículo 18; "Proyecto II", artículo 16: "La enseñanza religiosa figurará en los planes de estudio de todas las escuelas públicas de Chile para los alumnos cuyos padres o guardadores manifiesten al director del establecimiento su deseo de que la reciban sus hijos o pupilos. Darán esta enseñanza maestros nombrados de entre las personas autorizadas por los ordinarios para enseñar religión, y en caso de que el ordinario respectivo retire la autorización ya dada a un maestro, éste quedará privado del derecho de enseñar religión". 
es, obligatoria para los establecimientos educacionales pero opcional para los padres y alumnos: Colombia (1992, artículo 4); Croacia (1996 sobre la cooperación en el campo educativo y cultural); todos los acuerdos con los Länder alemanes (1996-1998); Letonia (2000, artículo 14-17); Eslovaquia (2000, artículo 13.6); Lituania (2000, sobre la cooperación en la educación y la cultura); Portugal (2004, artículo 19); Bosnia-Herzegovina (2006, artículo 16); Brasil (2008, artículo 11).

Paralelo a este derecho, todos los países que después del Concilio Vaticano II han renovado sus acuerdos con la Santa Sede, han reconocido el derecho de la Iglesia de fundar sus propios establecimientos educacionales sobre una base confesional: Colombia (1973, artículo X); España (1979 sobre enseñanza y cuestiones culturales, artículo IX-X); Italia (1984, artículo 9.1); y los cuatro Länder alemanes, reconocimiento que se encuentra también en los nuevos acuerdos celebrados con otros Estados, como Polonia (1993, artículo 14), Croacia (1996, artículo 8), Kazakistán (1998, artículo 7-8), Eslovenia (2001, artículo 10), Letonia (2000, artículo 18-19), Lituania (2000, artículo 8); Eslovaquia (2000, artículo 13), República Checa (2002, artículo 11), Portugal (2004, artículo 21), Bosnia-Herzegovina (2006, artículo 14).

\section{Artículo 17}

"[Inc. $\left.1^{\circ}\right]$ Los bienes pertenecientes a la Iglesia no serán sometidos a resoluciones o actos jurídicos que puedan modificar su destinación, sin el consentimiento de las autoridades eclesiásticas, salvo en los casos previstos en la ley referente a expropiaciones por causa de utilidad pública.

"[Inc. $2^{\circ}$ En estos casos la destinación de los inmuebles consagrados exclusivamente al culto divino, tales como las iglesias y sus dotaciones, será modificada una vez que la respectiva autoridad eclesiástica, notificada oportunamente, haya podido levantarle su carácter sagrado.

"[Inc. $\left.3^{\circ}\right]$ La construcción, modificación o restauración de iglesias o capillas quedan sometidas a las normas y a las condiciones de seguridad e higienefijadas por las leyes y ordenanzas que rijan en Chile sobre la materia".

Recogía, con leves cambios de redacción, en artículo 19 del "Proyecto I", transformado en el artículo 17 del "Proyecto II" ${ }^{45}$. Disponía el Código de

45 "Proyecto I", artículo 19; "Proyecto II", artículo 17: "[Inc. 1] Los bienes pertenecientes a la Iglesia no serán sometidos a resoluciones o actos jurídicos que puedan modificar su destinación sin consentimiento de las autoridades eclesiásticas, salvo en los casos previstos en la ley respecto de expropiaciones por causa de utilidad pública. [Inc. $2^{\circ}$ ] En estos casos la destinación de los inmuebles consagrados exclusivamente al culto divino, tales como las iglesias y sus dotaciones, será modificada una vez que la respectiva autoridad eclesiástica, notificada oportunamente, haya podido levantarles su carácter sagrado. [Inc. $3^{\circ}$ ] No se 
Derecho Canónico vigente en 1928 que "son lugares sagrados aquellos que se destinan al culto divino o a la sepultura de los fieles mediante la consagración o la bendición que a este efecto prescriben los libros litúrgicos aprobados" (canon 1154) y no perdían su consagración o bendición "a no ser que se las destruya completamente, o venga a tierra la mayorparte de susparedes, o sean reducidas a usos profanos por el ordinario local, a tenor del canon 118746" (canon 1170).

Normas similares se encuentran en concordatos recientes como el de Polonia (1993, artículo 8.3), Croacia (1996 sobre cuestiones jurídicas, artículo 11), Gabón (1997, artículo 10), Lituania (2000, artículo 6), Eslovaquia (2000, artículo 21.2), Portugal (2004, artículo 24), Bosnia y Herzegovina (2006, artículo 7), Brasil (2008, artículo $7 \$ 1)$, en algunos de los cuales se contempla la posibilidad de ocupar dichos bienes "por razones importantes", pero siempre se actuará en relación con la autoridad eclesiástica, a menos que se trate de una urgencia excepcional.

Artículo 18

"Los cementerios católicos podrán administrarse libremente en Chile, en conformidad con el derecho canónico y con la legislación actualmente en vigor".

Recogía, con una redacción nueva, el artículo 21 del "Proyecto I" ${ }^{\text {"4 }}$, que con un texto más restrictivo, pasó a ser el artículo 19 del "Proyecto II" ${ }^{48}$; el proyecto del nuncio agregaba el adverbio "libremente" que no estaba en el original. Puesto que, de acuerdo con el Código de Derecho Canónico de 1917, "son lugares sagrados aquellos que se destinan al culto divino o a la sepultura de los fieles mediante la consagración o la bendición que a ese efecto prescriben por los libros litúrgicos aprobados" (canon 1154), los cementerios debían considerarse lugares sagrados y el propio código les dedicaba diez cánones (canon 1205-1214), uno de los cuales afirmaba que "la Iglesia tiene derecho a poseer cementerios propios" (canon $1206 \$ 1$ ). Los concordatos post-conciliares, por lo general, no tienen referencias explícitas a los cementerios los que quedan

procederá a ninguna construcción, modificación o restauración de iglesias o capillas sino conforme a las prescripciones del derecho común, que estén en vigencia con respecto a tales trabajos".

${ }^{46}$ Código de Derecho Canónico (1917), canon 1187: "Si alguna iglesia no pudiera de ningún modo emplearse para el culto divino y estuvieran cerrados todos los caminos para su restauración, puede el ordinario local reducirla a usos profanos no sórdidos, trasladando él mismo a otra iglesia las cargas con las rentas y el titulo de la parroquia, si es una iglesia parroquial".

47 "Proyecto I", artículo 21: "Podrán establecerse y administrarse en Chile cementerios católicos de acuerdo con la legislación chilena y el derecho canónico".

48 "Proyecto II", artículo 19: "Podrán administrarse en Chile los cementerios católicos existentes de acuerdo con la legislación chilena y el derecho canónico". 
incluidos en el reconocimiento general que se hace a la Iglesia del derecho de poseer bienes. Puede mencionarse el concordato con Colombia (1973, artículo XXVII), que garantiza a la iglesia el derecho de poseer y administrar sus propios cementerios, que estarán sometidos a la vigilancia oficial en el referente a higiene y orden público; además, se reconoce a la Iglesia la posibilidad de ejercer su ministerio en la inhumación de sus fieles en los cementerios dependientes de la autoridad civil. Este artículo no ha presentado problemas de constitucionalidad ${ }^{49}$.

\section{Artículo 19}

"Queda reconocido el derecho que asiste a las autoridades eclesiásticas competentes para proveer los beneficios, oficios y cargos eclesiásticos en conformidad al derecho canónico; pero no podrán obtener en Chile beneficios parroquiales los extranjeros no nacionalizados, salvo que el gobierno diere autorización para el efecto".

Se recogía el artículo 23 del "Proyecto I" que, en los mismos términos, pasó a ser el artículo 21 del "Proyecto II" ${ }^{50}$, aunque el texto del nuncio le proporcionaba una nueva redacción, eliminando la prohibición que ambos artículos contenían para que no pudieren obtener beneficios parroquiales las personas que desarrollaren actividades contrarias al orden público o a la seguridad del Estado lo que, en opinión del nuncio, implicaba una especie de derecho de placet en el nombramiento de los párrocos, una nueva expresión del neo-regalismo de las autoridades chilenas que muestran estos proyectos. Sin embargo, conservaba la limitación de que no pudieren obtener en Chile beneficios parroquiales los extranjeros no nacionalizados, salvo que el gobierno diere autorización para el efecto; según explicaba el diplomático al cardenal secretario de Estado, la situación contemplada en la norma era de aplicación relativamente rara y no sería difícil obtener la autorización prevista para los párrocos extranjeros, recurriendo, cuando ocurriere, "a la amigable intervención del respectivo ministro".

Un simple repaso por los concordatos post-conciliares permite advertir el reconocimiento que ellos hacen de la libertad de las autoridades eclesiásticas para hacer los nombramientos al interior de la Iglesia, sin que queden

\footnotetext{
${ }^{49}$ Prieto, Vicente, cit. (n. 13), p. 183.

50 “Proyecto I", artículo 23; "Proyecto II", artículo 21: “Queda reconocido el derecho que asiste a las autoridades eclesiásticas competentes para proveer los beneficios, funciones y cargos eclesiásticos en conformidad al derecho canónico, pero en el territorio de Chile no podrán obtener beneficios parroquiales las personas que desarrollen actividades contrarias al orden público o a la seguridad del Estado, ni los extranjeros no nacionalizados, salvo, en el caso de estos últimos, que el gobierno diere autorización para el efecto".
} 
resabios de la exigencia establecida en los proyectos chilenos. En efecto, en el acuerdo con Argentina (1966) nada se dice de la provisión de beneficios parroquiales y en cuanto a los religiosos se reconoce el derecho del episcopado de llamar al país a las órdenes, congregaciones religiosas masculinas y femeninas y sacerdotales seculares que estimen útiles "para el incremento de la asistencia espiritual y educación cristiana del pueblo", sin que se establezca limitación alguna; por el contrario, el gobierno se compromete a facilitar "al personal eclesiástico y religioso extranjero" el permiso de residencia y la carta de ciudadanía "en armonía con las leyes pertinentes" (artículo V). En el acuerdo sobre cuestiones jurídicas con España (1979), nada se dice acerca del nombramiento de párrocos ni de autoridades religiosas, actuaciones eclesiales que quedan amparadas por la libertad que se reconoce a la Iglesia para el ejercicio libre y público de las actividades que le son propias (artículo 1), la misma "plena independencia y autonomía" que se le reconoce en el acuerdo con Perú (1980, artículo I) en el que se permite a las órdenes y congregaciones religiosas y los institutos seculares organizarse como asociaciones civiles "respetándose su régimen canónico interno" (artículo IX). Poco después, en el acuerdo con Italia con el que se modificó el concordato lateranense (1984), se reconoció expresamente que "el nombramiento de los titulares de oficios eclesiásticos es libremente efectuado por la autoridad eclesiástica" (artículo 3. 2 i.p.). La misma libertad se reconoce en el concordato con Polonia (1993, artículo 7), Croacia (1996 sobre cuestiones jurídicas, artículo 6) que reconoce el derecho de hacerlo conforme a las normas del derecho canónico, al igual que el acuerdo con Gabón (1997, artículo 7), con Lituania (2000 sobre aspectos jurídicos, artículo 6), República Eslovaca (2000, artículo 6), República Checa (2002, artículo 6). Más próximo a nosotros en el tiempo y en el espacio, el acuerdo con Brasil (2008, artículo 17), reconoce a los obispos, en el ejercicio de su ministerio pastoral, la posibilidad de invitar a sacerdotes, miembros de institutos religiosos y laicos, que no tengan nacionalidad brasileña, para prestar servicios en el territorio de sus diócesis y pedir a la autoridad civil, en nombre de ellos, la concesión de la visa para desarrollar actividades pastorales en el país; pero nada se dice en cuanto a limitaciones para nombrar sus autoridades, conservando la Iglesia su completa libertad.

Artículo 20

"Las autoridades de la República podrán formular acusaciones contra cualquier eclesiástico a causa de actividades contrarias al orden público o a la seguridad del Estado, en demanda de medidas eclesiásticas contra él. Estas acusaciones se presentarán al ordinario respectivo, el cual las considerará y, en caso de que las encontrare fundadas, tomará las medidas necesarias". 
Se recogía el artículo 24 del "Proyecto I" que pasó en los mismos términos a ser el artículo 22 del "Proyecto II" 51 , pero el texto propuesto por el nuncio eliminaba el último paso de los dos artículos anteriores, según el cual "si se produjere desacuerdo, lo resolverá una comisión compuesta de dos eclesiásticos nombrados por la Santa Sede y dos delegados nombrados por el gobierno". El nuncio eliminaba dicha comisión aunque estaba contemplada en el concordato con Polonia que en esta materia se había tenido a la vista. En la carta con la que enviaba estos proyectos al secretario de Estado le manifestaba que no veía inconvenientes en esta norma pues, con la nueva redacción que le había dado, el juicio sobre la eventual acusación contra el clero quedaba reservada a la autoridad eclesiástica.

Estamos ante un requerimiento que hacían las autoridades estatales ante la autoridad eclesiástica para que ella adoptase las medidas eclesiásticas necesarias. Además, se limitaba a actividades muy específicas, como son las contrarias al orden público o a la seguridad del Estado. Diverso es el caso de que la acusación se haga ante los tribunales estatales por estas mismas actividades. El artículo 23 del proyecto del nuncio, que analizo más adelante, se refería específicamente a los "crimenes previstos por las leyes penales de la República" cometidos por eclesiásticos o religiosos por los cuales eran acusados ante los tribunales del Estado. Así, este requerimiento ante la autoridad eclesiástica bien puede entenderse como una gestión de deferencia para con la Iglesia, antes de iniciar las acciones ante los tribunales estatales, en tiempos en que estaba aún vivo el privilegio del fuero, aunque por estos mismos años dicho privilegio empezada a desdibujarse. Es por lo que, si se miran los concordatos y acuerdos posteriores al Concilio Vaticano II, se advierte en ellos una total ausencia de una norma similar a este artículo 20, pues todas las acusaciones contra los clérigos se han reconducido a los tribunales del estatales, materia que analizaré más adelante con ocasión del artículo 23.

Artículo 21

"El Estado asegura plena libertad de organización y de funcionamiento a las Asociaciones, que persiguiendo fines principalmente religiosos hacen parte de la ACCIÓN CATÓLICA [sic] y dependen de la autoridad de los ordinarios”.

51 "Proyecto I", artículo 24; "Proyecto II", artículo 22: "Las autoridades de la República podrán formular acusaciones contra cualquier eclesiástico a causa de actividades contrarias al orden público o a la seguridad del Estado, en demanda de medidas eclesiásticas contra él. Estas acusaciones se presentarán al ordinario respectivo, el cual las considerará y resolverá, tomando las medidas adecuadas en el menor plazo posible. Si se produjere desacuerdo, lo resolverá una comisión compuesta de dos eclesiásticos nombrados por la Santa Sede y dos delegados nombrados por el gobierno". 
Se trataba de un artículo que no aparecía en ninguno de los dos proyectos anteriores, que el nuncio incorporaba ex novo y que él consideraba una de las grandes ventajas que tenía este proyecto y que justificaba las concesiones que se hacían al Estado. Un artículo similar se encontraba en el concordato con Lituania (1927, artículo XXV) que había servido de base a las autoridades chilenas para redactar los dos proyectos gubernamentales, pero que el gobierno había excluido de los mismos, ausencia que el nuncio subsanaba incorporando este nuevo artículo, que no era sino la traducción al castellano del texto lituano.

La especial referencia a la Acción Católica se explicaba por ser una de las organizaciones centrales en el pensamiento y el magisterio de Pío XI, al punto que puede afirmarse que "la Acción Católica fue, con mucho, el gran empeño de Pío XI. Creyó encontrar en ella el instrumento proporcionado a la gravedad y necesidades del tiempo que cubrió su pontificado. Fue una empresa singularmente ambiciosa la intentada por el papa, posiblemente la más ambiciosa de todas las empresas pontificias de la época contemporánea" ${ }^{52}$. Desde el principio de su pontificado se había referido a ella ${ }^{53} \mathrm{y}$, si bien en los primeros años lo hizo en términos similares a los pontífices anteriores, a partir de 1928, es decir, en los momentos en que se redactaban estos proyectos, Pío XI le dio un sentido original. El especial interés de Pío XI explicaba la expresa referencia a la Acción Católica en este proyecto, cuya libertad de organización y funcionamiento era necesario asegurar, pues, no obstante que se trataba de un apostolado auxiliar de la Iglesia y que "no tiene otra finalidad sino que los seglares participen en cierto modo en el apostolado jerárquico" ${ }^{54}$, no tenía personalidad jurídica canónica, por lo que, a pesar el interés del nuncio por la personalidad jurídica de la Iglesia, la Acción Católica no quedaba amparada por el artículo 3 de su proyecto, que reconocía libertad y derechos a "todas las personas juridicas eclesiásticas y religiosas reconocidas como tales por el derecho canónico".

Se trata de un artículo que tiene una justificación histórica, explicada por el momento que pasaba la Iglesia de esos años. De hecho, la crisis en que entró años después la Acción Católica, hace que en los concordatos posteriores al Concilio Vaticano II no haya ninguna norma similar a la que estoy analizando.

${ }^{52}$ Redondo, Gonzalo, Historia de la Iglesia, III: La Iglesia en la Edad Contemporánea (Madrid, Rialp, 1989), pp. 244-245.

${ }^{53}$ Pío XI, Encíclica 'Ubi arcano' (1922), en Acta Apostolicae Sedis, 14 (1922), pp. 686-690.

${ }^{54}$ Pío XI, Carta 'Quae nobis', al cardenal Bertram, arzobispo de Breslau (13 de noviembre de 1928), en Acta Apostolicae Sedis, 20 (1928), p. 385. 


\section{Artículo 22}

"La República de Chile reconoce el derecho de propiedad de las personas jurídicas eclesiásticas sobre todos los bienes muebles e inmuebles, capitales, rentas y otros derechos que las dichas personas juridicas poseen actualmente en el territorio del Estado".

Se trata, al igual que el artículo anterior, de una norma que no estaba en los proyectos gubernamentales, pero que aparecía en el concordato con Lituania (1927, artículo XXII), de donde la retoma el nuncio y la incorpora en su proyecto como artículo 22 , cuyo contenido es la mera traducción al castellano del artículo XXII. 1 del concordato lituano que, a su vez, recogía textualmente el artículo XXIV. 1 del concordato con Polonia (1925).

El sentido de este artículo en el concordato lituano, y también en el concordato polaco, parece que hay que entenderlo en atención a la situación histórica de la Iglesia en esas naciones por los años de dichos acuerdos, de la que alguna luz arroja el No 2 del mismo artículo según el cual la República de Lituania, y la de Polonia en su caso, consentían en que el derecho de propiedad a que se refería el $\mathrm{N}^{\circ} 1$, en el caso que no estuviera aún inscrito en los registros hipotecarios u otros instrumentos jurídicos equivalentes, a nombre de las personas jurídicas que los poseían, esto es, obispados, capítulos catedralicios, congregaciones, órdenes religiosas, seminarios, beneficios parroquiales, etc., podían inscribirse con una declaración del ordinario competente, certificada por la autoridad civil competente. En otras palabras, lo que se pretendía con estos artículos era regularizar la situación jurídica de los bienes de la Iglesia, estableciéndose en el $N^{\circ} 1$ una suerte de presunción de dominio de la Iglesia sobre los bienes que poseía a la fecha de la firma de los concordatos, cuya regularización se haría conforme al № 2 de la misma norma. Me parece, así, que el $N^{\circ} 1$ no puede entenderse sin el $N^{\circ} 2$, por lo que el $\mathrm{N}^{\circ} 1$ desgajado del resto de la norma pierde sentido y resulta poco inteligible.

Como el artículo original contemplado en los modelos tenidos a la vista se referían a una situación que no podía proyectarse sin más a la realidad chilena, ello explica su desaparición de los proyectos gubernamentales. Por lo demás, la materia tratada en este artículo estaba debidamente resguardada por el artículo 3 del proyecto del nuncio y ello explica que una norma similar no aparezca en los concordatos post-conciliares.

Artículo 23

"Si algún eclesiástico o religioso fuere acusado ante los tribunales chilenos porcrimenes previstos en las leyes penales de la República, el tribunal respectivo 
informará sin pérdida de tiempo al ordinario correspondiente y le trasmitirá el auto de acusación y, en su oportunidad, la sentencia con sus considerandos".

Se recogía textualmente el artículo 25 del "Proyecto I" que, sin modificaciones, pasó al "Proyecto II" con el número 23. Se trataba, pues, de un artículo que permanecía en todos los proyectos con la misma fórmula. Era la supervivencia, muy disminuida por cierto, del viejo privilegio del fuero según el cual los eclesiásticos que cometían delitos comunes sancionados por la legislación civil debían ser juzgados por tribunales eclesiásticos, privilegio que en los concordatos decimonónicos había empezado a sufrir restricciones ${ }^{55}$.

En los concordatos vigentes, el concordato con Colombia (1973, 1992, artículo XIX) dispone que los clérigos y religiosos serán sometidos a los tribunales del Estado cuando cometan "delitos ajenos al ministerio eclesiástico"; la discusión se ha centrado en los obispos, pues se ha solicitado la declaración de inconstitucionalidad de aquella parte de la norma según la cual "se exceptúan los procesos penales contra los obispos y quienes están asimilados a estos en el derecho eclesiástico, que son de competencia exclusiva de la Sede Apostólica" ${ }^{\text {6 }}$. En el acuerdo con España (1976, artículo II. 2), lo único que queda del fuero es una notificación al respectivo ordinario, tratándose de clérigos o religiosos, y a la Santa Sede cuando se trate de obispos. En Italia (1984) no subsiste nada del viejo privilegio del fuero. Más recientemente en Croacia (1996, artículo 8. 1) en el caso de que se instruya proceso contra un eclesiásticos por delitos contemplados en el Código Penal, la autoridad judicial informará previamente a la autoridad eclesiástica competente. En el acuerdo con Gabón (1997, artículo $8 \$ 1-2$ ) cualquier denuncia, información o acciones legales contra un clérigo o un religioso sobre la base de eventuales comportamientos incompatibles con la ley civil o penal, salvo el caso de delito flagrante o condena definitiva, la autoridad judicial comunicará preventiva y confidencialmente al obispo del lugar de residencia del interesado los motivos de tal acción legal; tratándose de religiosos, la información será a su superior directo. En el de Lituania (2000, artículo 8.2) se dispone que, en el caso de prepararse un procedimiento penal contra un miembro del clero, la institución legal pertinente, "en consideración de su responsabilidad pastoral frente a sus fieles, lo informará a la autoridad eclesiástica competente, a condición de que no influy a negativamente sobre el procedimiento de investigación". Y, en esta misma tónica general, en el acuerdo con Bosnia-Herzegovina (2006, artículo 8.1), se establece la información previa a la autoridad eclesiástica respectiva. En síntesis, el derecho concordatario moderno ha dejado de

\footnotetext{
${ }^{55}$ Para esta evolución véase Minnerath, Roland, cit. (n. 25), pp. 290-311.

${ }^{56}$ Prieto, Vicente, cit. (n. 13), pp. 167-169.
} 
lado el viejo privilegio del fuero, aceptando la Iglesia que los clérigos y los religiosos sean juzgados por los tribunales del Estado cuando han cometido delitos comunes, pero se ha hecho común una notificación a la autoridad eclesiástica que corresponda. Y cuando se trata de clérigos, quedan en ellos incluidos los obispos y sus equiparados, si bien la notificación, en este caso, se hace a la Santa Sede.

\section{Artículo 24}

"En caso de arresto o de prisión de un eclesiástico o religioso, las autoridades civiles procederán con todas las consideraciones debidas a su carácter o rango eclesiástico y, en cuanto lo permitan las condiciones y el régimen del establecimiento penal en que debiere ingresar, se le señalará local de reclusión separado, a menos que el ordinario competente lo hay a privado de la dignidad eclesiástica".

Recogía el artículo 26 del "Proyecto I" que pasó, casi sin modificaciones ${ }^{57}$, a ser el artículo 24 del "Proyecto II", que fue recibido textualmente en el artículo 24 del proyecto del nuncio. Recogía este artículo uno de los aspectos del privilegio del fuero que por esos años se batía en retirada. En efecto, en los concordatos posteriores al Concilio Vaticano II, Colombia (1973, artículo 20; 1992, artículo 7), se dispone que en la detención o arresto de un clérigo, antes y durante el proceso, no podrán ser recluidos en cárceles comunes, pero si fueren condenados en última instancia se les aplicará el régimen ordinario sobre ejecución de las penas. Se ha alegado la inconstitucionalidad de este artículo porque "el establecimiento de normas especiales de procedimiento penal para el juzgamiento de clérigos y religiosos instituye un tratamiento preferencial frente a los demás procesados". Por su parte, en la legislación ordinaria colombiana se ha pasado de un reconocimiento inicial expreso del concordato a normas de procedimiento penal que no incluyen referencia alguna a situaciones de excepción para obispos, sacerdotes y religiosos, de manera que en el caso de sacerdotes y religiosos se ha venido aplicando la legislación ordinaria, sin tener en cuenta las normas concordatarias ${ }^{58}$.

En España, el acuerdo de 1976 (artículo II. 1), derogó el artículo XVI del concordato de 1953, en cuyo número 5 se disponía que, en caso de detención o arresto, los clérigos y religiosos serían tratados con las consideraciones debidas a su estado y a su grado jerárquico, por lo que las penas de privación de libertad serían cumplidas en una casa eclesiástica o religiosa que, a juicio del ordinario del lugar y de la autoridad judicial del Estado, ofreciera las

\footnotetext{
57 "Proyecto I": "su carácter y rango eclesiástico"; "Proyecto II": "su carácter o rango eclesiástico".

${ }^{58}$ Prieto, Vicente, cit. (n. 13), pp. 167-169.
} 
convenientes garantías; o, al menos, en locales distintos de los que se destinan a los seglares, a menos que la autoridad eclesiástica competente, utilizando terminología de la época, hubiera reducido al condenado al estado laical. En el acuerdo con Italia (1984) no subsistió nada del privilegio del fuero. Y en los concordatos posteriores nada se ha dicho sobre este particular.

Artículo 25

"Quedan derogadas todas las disposiciones legales, reglamentarias o administrativas vigentes en Chile que fueren contrarias a las que el presente concordato contiene".

Se recogía en forma textual el artículo 27 del "Proyecto I", que pasó a ser el artículo 25 del "Proyecto II". Se trataba de una cláusula que se encuentra en el concordato de Colombia (1973, artículo XXX inciso $2^{\circ}$ ), pero que no suele encontrarse en los acuerdos parciales como los celebrados con España (1979), ni aparece en algunos de los acuerdos marcos o generales más recientes como el de Polonia (1993), Gabón (1997), Letonia (2000), República Eslovaca (2000), Bosnia-Herzegovina (2006), Brasil (2008), ni en los acuerdos con Croacia $(1996,1997)$ y Lituania (2000). En un sentido diverso, mirando a la puesta en práctica del acuerdo, en el celebrado con Portugal (2004, artículo 32) se dispone que la Santa Sede y la República Portuguesa procederán a la elaboración, revisión y publicación de la legislación complementaria eventualmente necesaria, para lo cual efectuarán consultas recíprocas.

Artículo 26

"El presente Concordato será ratificado y sus ratificaciones serán canjeadas en ... [sic] tan pronto como sea posible".

Recogía el artículo 26 del “Proyecto II” que reproducía el artículo 28 del "Proyecto I", con una diferencia, pues mientras el primero afirmaba que las ratificaciones serían canjeadas "en esta capital", el segundo decía que dichas ratificaciones serían canjeadas en Roma; es por lo que el nuncio no señala lugar alguno, dejando el señalamiento del lugar para otro momento.

Entre los concordatos y acuerdos post-conciliares la mayoría no fijan lugar alguno, como los de Colombia (1973); Ecuador, sobre asistencia religiosa a las Fuerzas Armadas (1978); España, acerca de cuestiones jurídicas (1979), sobre enseñanza y cuestiones culturales (1979) y sobre cuestiones económicas (1979); Perú (1980); Principado de Mónaco (1981); Bolivia, sobre asistencia religiosa a las Fuerzas Armadas (1986); Israel (1993); Venezuela, para la creación de un ordinariato castrense (1994); Croacia (1996); Kazakistán (1998); Letonia (2000); República Eslovaca (2000); Gabón, sobre 
la educación católica (2001); Albania (2002); República Checa (2002); Bosnia-Herzegovina (2006); Brasil (2008). Los menos fijan alguna ciudad del Estado signatario, como el de Alemania, Saarland (1975: Saarbrücken), Alemania, Baviera (1978: Bonn); o derechamente Roma, como el acuerdo adicional con Austria sobre relaciones patrimoniales (1976). Incluso, algunos no dicen expresamente dónde se hará la ratificación, pero dan cuenta de haberse realizado en la Ciudad del Vaticano, como los de Lituania, sobre cooperación en la educación y la cultura (2000), sobre cuestiones jurídicas (2000) y sobre asistencia religiosa católica en las Fuerzas Armadas (2000) y el de Polonia (1993); o en la ciudad de Madrid, como el acuerdo con España (1976) y sobre cuestiones económicas (1979); o en la ciudad de Bonn, como el acuerdo de Alemania, Niedersachsen (1993).

Por lo general, a diferencia de la fórmula utilizada en Chile en 1928, los concordatos y acuerdos actuales, añaden en esta cláusula que la entrada en vigencia de dichos textos se producirá precisamente en el momento del intercambio de las ratificaciones; aunque los hay que dicen que la entrada en vigencia se hará al día siguiente a dicho intercambio de instrumentos de ratificación como sucede con los acuerdos con diversos Länder alemanes con ocasión de la erección de nuevas diócesis (1994) o el celebrado con el Estado libre de Turingia (Alemania, 1997). Sólo ocasionalmente dicen que dicho intercambio haya de producirse "tan pronto como sea posible", como sucede en el acuerdo con Bolivia sobre asistencia religiosa a las Fuerzas Armadas (1986), o en un acuerdo similar con Hungría (1994).

\section{Artículo 27}

"La vigencia de este Concordato será de 50 años contados desde el día del canje de sus ratificaciones; pero, vencido este término, continuará en vigor hasta que una de las partes signatarias notifique a la otra, con aviso previo de un año, su resolución de ponerle término".

Recogía el artículo 27 del "Proyecto II" que repetía, a su vez, el artículo 29 del "Proyecto I" vigencia, pues, mientras el gobierno de Chile en sus dos proyectos proponía una vigencia de 10 años, el proyecto del nuncio sugería 50 años.

Por lo general, los concordatos y acuerdos post-conciliares no contienen una cláusula en la que se fije la duración del mismo, como los de Colombia (1973), España (1979), Perú (1980), Polonia (1993), los acuerdos con

59 "Proyecto I", artículo 29; "Proyecto II", artículo 27: "La vigencia de este concordato será de diez años contados desde el día del canje de sus ratificaciones, pero vencido este término continuará en vigor hasta que una de las partes notifique a la otra, con aviso previo de un año, su resolución de ponerle término". 
Croacia (1996), Gabón (1997), Letonia (2000), República Eslovaca (2000), Bosnia-Herzegovina (2006), Brasil (2008), para centrarme sólo en algunos, lo que significa que las partes le conceden una duración indeterminada, lo que en algún caso, como el de la República Checa (2002), se dice expresamente. Hay alguno, empero, que contiene dicha cláusula, como el de Kazakistán (1998), que fija el término de 10 años, prorrogándose automáticamente por los quinquenios siguientes hasta que una de las partes envíe dentro de seis meses, una notificación escrita con el deseo de suspender la validez del acuerdo. En cuanto a la posibilidad de denuncia del mismo, no se encuentra frecuentemente en los acuerdos post-conciliares, aunque hay algunos que la contienen como el acuerdo con Brasil sobre asistencia religiosa a las Fuerzas Armadas (1989), fijándose, al igual que en el proyecto chileno, un año de anticipación.

\section{Conclusión}

El tercero de los proyectos de concordato entre Chile y la Santa Sede, redactado por el nuncio apostólico en Chile, cierra el ciclo de proyectos redactados una vez producida la separación Iglesia-Estado en la Constitución de 1925. A lo largo de su articulado, el representante pontificio intentó superar los intentos neo-regalistas que se advertían en el "Proyecto II" del gobierno chileno, que era el que el diplomático había conocido y que se mostraba más regalista que el "Proyecto I", que el nuncio desconocía.

No obstante estos esfuerzos, perduraban en el proyecto del representante papal algunos resabios de dicho regalismo, que se explican, en parte, por un deseo de agradar al gobierno en aras a obtener la firma del concordato y, en parte, por el deseo del prelado de permanecer apegado al concordato que le servía de modelo, el concordato con Lituania del año anterior, en el que dichos resabios se hallaban presentes, pero que no eran sin más trasladables a la realidad chilena, en la que en los meses anteriores a estos proyectos se habían empezado a originar cambios que durarían en el tiempo, pero que no quedaban reflejados en este texto.

Una mirada a los no escasos concordatos que se han firmado después del Concilio Vaticano II y que permanecen vigentes muestra que parte importante de las materias reguladas en el articulado de este proyecto se encuentran también en ellos, con regulaciones que, recogiendo los avances del moderno derecho concordatario, no han variado en lo sustancial y que permiten, por lo mismo, utilizarlo, junto con los otros dos proyectos, como punto de partida para pensar en los contenidos de un posible futuro concordato entre Chile y la Santa Sede. 


\section{BiBLIOgRAFÍA}

Alessandri Rodríguez, Arturo - Somarriva Undurraga, Manuel, Curso de Derecho Civil (redactado y puesto al día por Antonio Vodanovic, $3^{a}$ edición, Santiago, Nascimento, 1961), I, 2.

Alessandri Rodríguez, Arturo, Derecho civil. Primer Año (versiones taquigráficas de sus clases tomadas por Onías León Gaete) (Santiago, Zamorano y Caperán, 1943).

Archivo Secreto Vaticano, Sacra Congregazione degli Affari Ecclesiastici Straordinari, Cile 1927-1928. Esta documentación ha sido transferida en el verano europeo de 2012 al Archivo de la Secretaría de Estado donde actualmente se encuentra.

Balmaceda Lazcano, C., El estatuto de las personas jurídicas (Santiago, Nascimento, 1943).

Código Civil de Chile (1956).

Código de Derecho Canónico (1917).

Concilio Vaticano II, Declaración 'Dignitatis humanae'(1965).

El conflicto eclesiástico de Tacna. Antecedentes y documentos oficiales, en La Revista Católica, 240 (1911).

Enchiridion dei concordati. Due secoli di storia dei rapporti Chiesa-Stato (2003) (Bologna, Dehoniane, 2003).

GonzÁlez Errázuriz, Juan Ignacio, Iglesia y Fuerzas Armadas. Estudio canónico y jurídico sobre la asistencia espiritual a las Fuerzas Armadas en Chile (Santiago de Chile, 1994).

Martín De Agar, José, I concordati dal 2000 al 2009 (Città del Vaticano, Libreria Editrice Vaticana, 2010).

Minnerath, Roland, L'Église catholique face aux États. Deux siècles de pratique concordataire 1801-2010 (Paris, Les Éditions du Cerf, 2012).

Овispos de Chile, Pastoral colectiva de los obispos de Chile, sobre la separación de la Iglesia y el Estado, en La Revista Católica, 578 (1925).

Pío X, Breve 'In hac beatissimi Petri cathedra' (3 de mayo de 1910), en Acta Apostolicae Sedis, 2 (1910).

Pío XI, Carta 'Quae nobis', al cardenal Bertram, arzobispo de Breslau (13 de noviembre de 1928), en Acta Apostolicae Sedis, 20 (1928).

Pío XI, Encíclica 'Ubi arcano'(1922), en Acta Apostolicae Sedis, 14 (1922).

Prieto, Vicente, Los acuerdos vigentes entre Colombia y la Santa Sede, en Navarro Floria, Juan G. (coordinador), Acuerdos y concordatos entre la Santa Sede y lospaises americanos (Buenos Aires, Editorial de la Universidad Católica Argentina, 2011.

Redondo, Gonzalo, Historia de la Iglesia, III: La Iglesia en la Edad Contemporánea (Madrid, Rialp, 1989).

Salinas Araneda, Carlos, Lecciones de derecho eclesiástico del Estado de Chile (Valparaíso, Ediciones Universitarias de Valparaíso de la Pontificia Universidad Católica de Valparaíso, 2004).

Salinas Araneda, Carlos, Un intento de neo-regalismo en el siglo XX: los proyectos de concordato entre Chile y la Santa Sede en 1928, en Anuario Jurídico y Económico Escurialense, 47 (2014)8.

Salinas Araneda, Carlos, Un primer proyecto de concordato entre Chile y la Santa Sede, en Revista Chilena de Derecho, 39 (2012). 
